\title{
Demand response in the Nordic electricity market
}

Input to strategy on demand flexibility

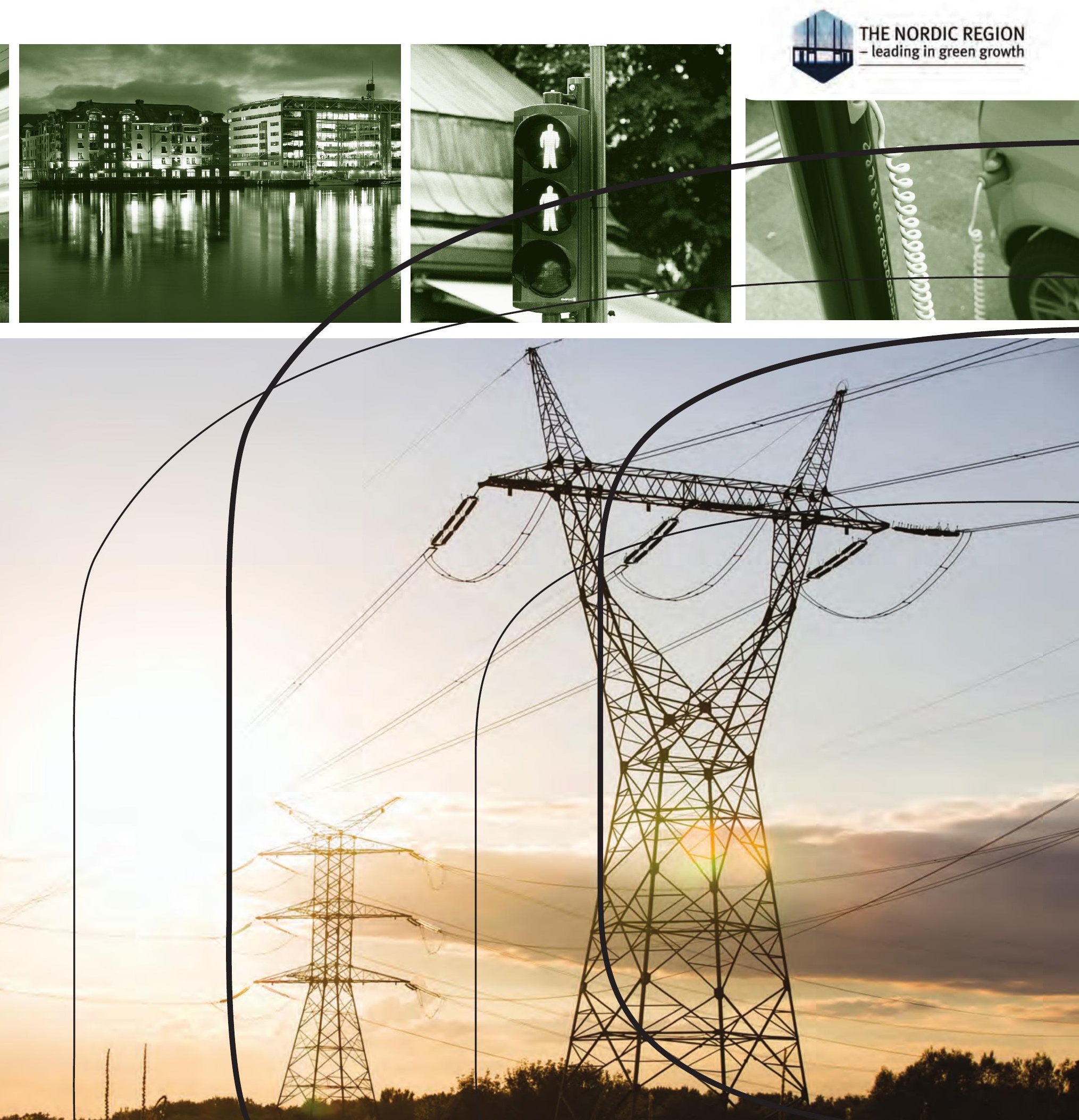



4 norden 



\section{Demand response in the Nordic electricity market}

Input to strategy on demand flexibility

THEMA Consulting Group 
Demand response in the Nordic electricity market Input to strategy on demand flexibility

THEMA Consulting Group

ISBN 978-92-893-3771-7 (PRINT)

978-92-893-3790-8 (PDF)

ISBN 978-92-893-3773-1 (EPUB)

http://dx.doi.org/10.6027/TN2014-553

TemaNord 2014:553

ISSN 0908-6692

(C) Nordic Council of Ministers 2014

Layout: Hanne Lebech

Cover photo: ImageSelect; Signelements

Print: Rosendahls-Schultz Grafisk

Copies: 116

Printed in Denmark

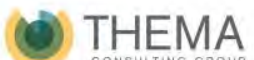

This publication has been published with financial support by the Nordic Council of Ministers. However, the contents of this publication do not necessarily reflect the views, policies or recommendations of the Nordic Council of Ministers.

www.norden.org/en/publications

\section{Nordic co-operation}

Nordic co-operation is one of the world's most extensive forms of regional collaboration, involving Denmark, Finland, Iceland, Norway, Sweden, and the Faroe Islands, Greenland, and Åland.

Nordic co-operation has firm traditions in politics, the economy, and culture. It plays an important role in European and international collaboration, and aims at creating a strong Nordic community in a strong Europe.

Nordic co-operation seeks to safeguard Nordic and regional interests and principles in the global community. Common Nordic values help the region solidify its position as one of the world's most innovative and competitive.

\section{Nordic Council of Ministers}

Ved Stranden 18

DK-1061 Copenhagen K

Phone (+45) 33960200

www.norden.org 


\section{Content}

1. Summary and Conclusions ..............................................................................................

1.1 How may demand flexibility contribute?....................................................... 7

1.2 The willingness to pay for flexibility varies in space and time .......................

1.3 The future value of flexibility is uncertain ........................................................

1.4 The cost efficiency of demand flexibility is uncertain ..................................... 10

1.5 Input to a Nordic strategy on demand flexibility ………................................ 11

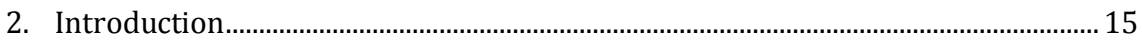

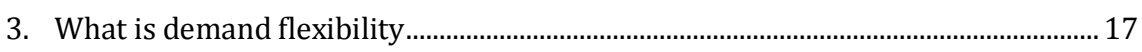

3.1 Definition of demand flexibility...................................................................... 17

3.2 How may demand flexibility contribute to increase efficiency?.................... 18

3.3 Different types of demand flexibility ............................................................... 19

3.4 The characteristics of demand flexibility.......................................................... 19

4. Supply and demand for Flexibility in the Nordic region................................................. 23

4.1 What defines the need for flexibility in the power system?.......................... 23

4.2 The value of flexibility varies across the Nordic region .................................. 24

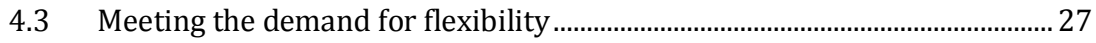

4.4 The consumer side is partly flexible .................................................................... 34

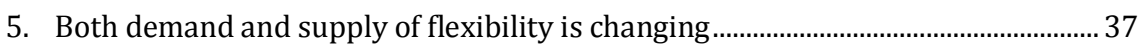

5.1 Summary of main uncertainties and developments ....................................... 38

5.2 Changes in generation ..................................................................................... 40

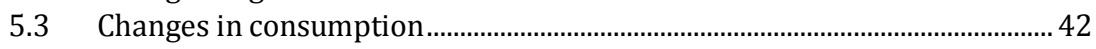

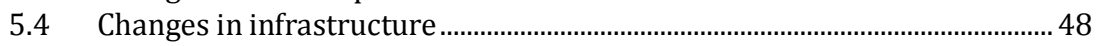

5.5 Developments in market solutions and regulation ..........................................50

6. How can demand flexibility be efficient? ................................................................ 57

6.1 Estimated potential for demand flexibility ..................................................... 57

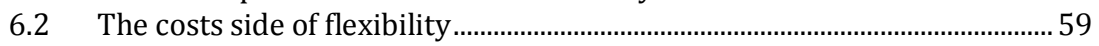

6.3 Are the consumers faced with efficient price signals? .................................... 63

6.4 Possible measures to more efficiently use demand flexibility....................... 66

7. Input to a nordic strategy for demand response........................................................... 79

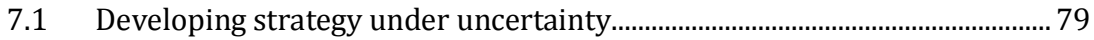

7.2 Overall recommendations for all Nordic countries.......................................... 81

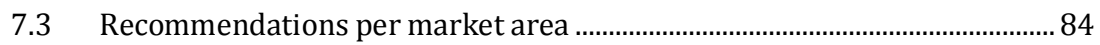

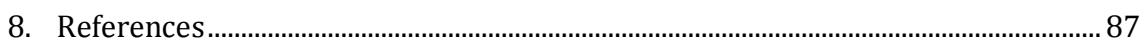

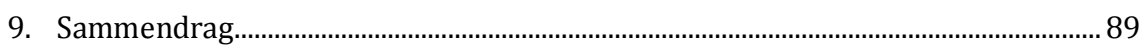

9.1 Forstå etterspørselen etter fleksibilitet bedre ................................................. 90

9.2 Utnytte billig fleksibilitet før dyr fleksibilitet gjennom effektive markeder ....................................................................................................... 91

10. Attachment 1: List of interviewees............................................................................. 93 



\section{Summary and Conclusions}

Planning and operating a power system can be challenging since production and demand must be exactly equal at all times, bottlenecks must be immediately addressed and capacity constraints in the network respected. A certain level of flexibility in the system is necessary in order to address critical situations when they arise. Today, such flexibility is provided by generators as flexibility on the consumer side is generally low.

In order to reduce greenhouse gas emissions from power generation, the power systems in the Nordic countries, as well as in the rest of $\mathrm{Eu}-$ rope, are profoundly changing. In parallel with the "greening" of electricity generation by increased use of renewable energy resources, electricity consumption should be reduced through increased energy efficiency. However, renewable electricity generation such as small-scale hydropower, wind and solar has limited capacity to deliver flexibility to the power system. Hence, it is relevant to consider to what extent the provision of flexibility from the consumer-side could and should be facilitated.

This report is commissioned by the Nordic Electricity Market Group (Nordic Council of Ministers) and provides input to a Nordic strategy on how to address the potential need for consumer flexibility in a costefficient manner.

The report is part of the Nordic Prime Ministers' green growth initiative: The Nordic Region - leading in green growth. Read more in the web magazine Green Growth the Nordic Way at www.nordicway.org or at www.norden.org/greengrowth

\subsection{How may demand flexibility contribute?}

In our context, demand flexibility can be defined as a willingness to change volumes of electricity consumed for short or long periods of time as a response to market prices, price incentives in grid tariffs or other economic incentives. The value of demand side flexibility varies significantly depending on such characteristics as volume, reliability and a range of different time-related aspects, e.g. duration, response time and recovery time.

Two conditions must be met in order to provide more active demand response: 
- There must be a demand for flexibility.

- Demand flexibility must be able to compete with other flexibility resources (generation, grid investments and storage), i.e. the demand side must be able to deliver the valued characteristics of flexibility in a cost efficient manner.

Demand flexibility may increase cost efficiency in the Nordic power markets in several ways:

- Improved price formation: If the demand side is inelastic, power price formation will depend on the generation side alone. With increasing generation from intermittent technologies, the risk of very high prices in peak load periods increases. The total risk is also linked to other developments in the Nordic power system, e.g. the total power balance and investments in transmission and interconnectors. However, more price sensitive electricity consumption will mitigate this risk, as well as the potential market power of electricity generators in peak periods.

- Provision of system services: The purpose of system services is to maintain the balance of electricity generation and consumption in real-time, and to maintain security of supply in all areas of the power system. The generation side is the main provider of the flexibility needed for system services today, but even some large consumers are active in these markets. The geographical location of flexibility is often crucial for system services, and in some areas the demand side may be the only provider.

- Reduced investments in the regional or local grid: If consumption growth drives investments in the regional or local grid, peak load reductions may reduce grid investments. Peak load is normally reached during a few hours of the day in the time of year when energy consumption is high (normally cold winter days in the Nordic countries). Reduction in peak load may be obtained by shifting loads from these hours to other times of the day.

In order to obtain the desired effects from increased demand flexibility, it is important that the flexibility fulfils a certain set of characteristics. The exact nature of these characteristics depends on the markets within which one aims to operate. The characteristics concern mainly the volume and various time aspects, such as duration and response time of load changes and the recovery time between such changes.

Consumer flexibility is mainly about disconnecting loads, but for some types of flexibility it can also be relevant to connect or increase loads. For instance, it can be useful for the power system to e.g. increase consumption in surplus situations when power prices are very low. 


\subsection{The willingness to pay for flexibility varies in space and time}

The willingness to pay for flexibility varies across time and geographical areas in terms of both the type of flexibility and the amount of flexibility. The variations are due to differences in the generation mix and consumption patterns, as well as the extent to which network capacity allows trade in flexibility between areas. In the Nordic market bidding zones (price areas) are established to make the market reflect these differences. In the long-term both generation and consumption may fluctuate due to economic development, new technology and politics. In an area dominated by e.g. stored hydro and large industry daily flexibility is abundant, but there is a need for flexibility to balance seasonal fluctuations in hydrology. In an area dominated by wind generation and household consumers flexibility is needed to balance daily fluctuations in wind and consumption (e.g. challenging peak-loads).

\subsection{The future value of flexibility is uncertain}

The Nordic power system is facing changes on both the generation and consumption side, markets are becoming increasingly integrated and efficient and bottlenecks in the grid are being reduced towards 2025 . How these changes will influence the power system, the power markets and the overall willingness to pay for flexibility is not fully understood. Development on different areas of the power system drives the value of flexibility in opposite directions, this results in uncertainty related to the future demand for flexibility (both in terms of volumes and the characteristics of the flexibility demanded). Some key uncertainties include:

- Variations in the spot price (price volatility) will probably increase due to more intermittent generation in the system and increased interconnector capacity between the Nordics and other European countries. On the other hand, increased transmission capacity and a positive power balance within the Nordic market should reduce the price volatility within each bidding zone. Hence, the impact on both the level and the duration of price variations are uncertain.

- Some volumes that participate in the markets for system services will be lost mainly due to reduced demand from power intensive industries and the phase out of combined oil and electric burners. This indicates that the competition in these markets will be reduced and that the willingness to pay may increase. On the other hand, we expect available resources to be utilized more efficiently across borders and regions when new market solutions and increased transmission and interconnector capacity are in place. However, it is 
uncertain how the competition to supply and the willingness to pay for system services will develop.

- Based on interviews carried out within the project, we find that, in general, the capacity in the distribution grids is sufficient. However, there is a risk that peak loads may increase if/when new appliances with high power loads are introduced. On the other hand, it is also uncertain how close to the capacity limit today's peak load levels are. If and when tools for measuring of actual loads (smart meters and other Smart Grid components) are introduced, the actual situation will be revealed. Hence, the relevance of reducing peak loads should analyzed in more detail.

\subsection{The cost efficiency of demand flexibility is uncertain}

The need for flexibility in the power system can be met by resource on the supply side, storage of power/heat, grid expansions and interactions with other energy systems such as heating and gas, and by demand flexibility. The competitiveness of the demand side in delivering flexibility depends on the cost of demand flexibility and the availability alternative flexibility in the market. Whether the demand response in the relevant area has the characteristics of the flexibility demanded, is an additional question. Descriptions of the potential for consumer flexibility often lack the detailed characteristics of this potential - and thereby cloud the technical potential to deliver flexibility services.

One should assume that the value consumers derive from using electricity is always higher than the total cost. Interrupting loads implies a cost associated with reduced production of energy services or comfort levels. This cost is normally considerable, which is why the price sensitivity of electricity consumption generally is low in the first place.

Demand response that does not include consequences for production of energy based services or comfort level may only be possible for loads when:

- An alternative energy source is installed as a back-up for electricity (normally the alternative source will be an oil burner).

- The load may be shifted in time due to:

a) Inertia - the temperature in a building or process will not change instantly if electricity supplies are interrupted.

b) There are storage possibilities - either for energy (battery or heat storage) or cache in a production process.

c) The load has excess capacity - it is not in use at all times and the usage may be shifted to hours of low cost. 
Efficient demand response depends on technology and equipment enabling automatic processing of data and calculation of the most economically viable response. Smart meters are also a vital component that will be installed in all the Nordic consumers before 2020. However, large consumers (including large buildings) have had smart meters for years without increasing the price sensitivity of the demand side. Hence, new and improved data will also be needed to enable different types of demand response:

- Hourly measuring, in addition to simple access to price signals, is a prerequisite to give the consumer price incentives to respond to variations in hourly spot prices or hourly time of use tariffs.

- To enable load changes as deliveries of system services, the response signal must be sent in a safe manner.

- To enable real-time demand response, real-time consumption data must be available directly from the smart meters.

The cost of time and focus required by the consumers is often underestimated when considering the potential for energy efficiency and demand response. Such costs may represent important barriers for the enabling of the demand flexibility potential, and even for the potential that may be economically viable. The smaller the loads in question, the larger the impact of cost of time and focus on unleashing the economic potential of demand response. In order to reduce costs, small loads (buildings) must be handled in a simple and standardized way - or they will not be cost efficient compared to larger loads (industry).

\subsection{Input to a Nordic strategy on demand flexibility}

\section{No specific measures to promote demand flexibility should be implemented without a better understanding on how the value of (demand) flexibility will develop in view of the likely changes in the Nordic power system}

Consumer flexibility is often mentioned as a solution that can contribute to improved price formation in spot markets, increased supply of system services, and potentially reduced local grid investments and operation costs.

A condition for developing specific measures for efficient utilization of consumer flexibility is that the sum of future challenges in the Nordic power system is well understood, included how the fundamental need for and value of flexibility may develop.

Whether demand side flexibility can compete with flexible generation or grid investments on costs, or will be able to deliver the needed types of flexibility, is currently not known. No specific measures to promote demand flexibility should be implemented without a better understand- 
ing on of how changes in power generation, demand, grid structures, technology and regulation are likely to affect the magnitude and characteristics of the demand for flexibility in the Nordic power system. If increased knowledge reveals areas where the need for flexibility has a high economic value and may be challenging to meet, further efforts should be focussed at these areas. Specific measures addressing demand response should focus on correcting market failures.

Future studies of flexibility potentials should differentiate potentials according to the characteristics of different loads (such as duration and response time for changes in load, and how long loads must be active inbetween disconnections). Technical potential estimates alone are only relevant when combined with assessments of the economic potential of existing (or expected) price signals and regulatory frameworks.

The impact of the full roll-out of smart meters with hourly measurement in Finland (and other areas of early movers in other Nordic countries) on demand flexibility should be monitored and evaluated.

\section{The efficiency of the Nordic power market is generally high, but further development of the market design can contribute to increase the efficiency of (consumer) flexibility}

During the last 20 years, the integration of the power markets in the Nordic countries has increased, and thereby, also the liquidity in the integrated markets. Further integration is expected, with a common Nordic end-user market, reduction of bottlenecks in the transmission grid, common balance settlement, and some common markets for system services are under implementation. All these developments contribute to increased integration and efficiency in the Nordic market. However, there are still some areas where efficiency can be increased further.

Consumer flexibility should preferably be clarified before the operational hour. Hence, consumer flexibility should be utilized in the spot market rather than in balancing markets when possible. Increased granularity of time resolution in the spot markets (e.g. from one hour to 15 minutes) and bidding closer to the operational hour could make more short-term flexibility available to the market, and reduce the need for balancing. More efficient allocation of grid capacity and redefinition of bidding zones, namely so that they are only defined by congestions (and not country borders) could cater for more efficient spot price formation as well.

A specific measure to ensure that consumer flexibility is not moved from spot markets to balancing market is to make aggregators balance responsible parties.

Balancing markets can be improved by increased integration among the Nordic countries and harmonized product definitions across borders. Should balancing markets not be further integrated, product definitions should be reconsidered in each country. Reduced bidding sizes (from 10 to $5 \mathrm{MW}$ is now tested), the duration of load adjustments, response times, and intervals between disconnections are (non-exhaustive) examples of 
product characteristic that should be assessed. Also the need and possibility to impose mandatory provisions of system services from the demand side, e.g. frequency control, should be investigated.

The introduction of standard data formats on relevant price signals to support the development of technology and services for energy management would promote efficiency

As stated, specific measures to promote demand flexibility should not be implemented without a better understanding of the future value of such flexibility. An exception should be made for low-cost measures with an expected positive future value. Imposing standard data formats for price signals in the power contract, tariffs and other relevant data will reduce the cost of automated demand response from small consumers. Cost efficient automation is a precondition for the development of technology and services for energy management based on price signals. In addition to promoting demand response, such automation will also promote energy efficiency. Nordic coordination could further increase the market potentials for new technology and energy services.

Grid tariffs should reflect the underlying grid costs to yield efficient demand response

Grid tariffs according to marginal losses, interruptible contracts and capacity pricing may incentivize increased end-user flexibility. Such grid tariffs should however not be implemented in order to increase flexibility, but in order to reflect underlying grid costs more efficiently. 



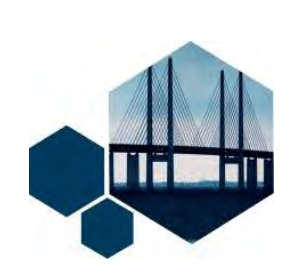

\section{Introduction}

This report summarises the results of a study commissioned by the Nordic Electricity Market Group (Nordic Council of Ministers). It is part of the Nordic Prime Ministers' green growth initiative, "The Nordic Region leading in green growth". The initiative identifies eight priorities aimed at greening the Nordic economies, one of which is to promote flexible consumption of energy. The overall aim of this project is to give input to a Nordic strategy on how to promote demand flexibility in the Nordic power system in an efficient manner.

Generation and consumption have to always balance in the power system at all times. Power systems have since the start of the industrial revolution been expanded and developed to cater for a steady growing demand for electricity. The perspective has been to ensure security of supply at a national level, and power has in most cases been provided by one or a few large utilities owning both generation and networks. The dominant provider of flexibility to balance variations in load has been the generators themselves, but power intensive industry has to some extent also contributed with flexibility.

The way the power system is balancing is now changing in a very profound way and in many respects. First, the supply side is in a transition to become emission free and fossil fuelled generation is replaced with renewables. Second, the demand side is affected by economic downturn, enhanced energy efficiency, replacements of oil burners and new consumption patterns that may increase the peak loads (charging of EVs, tankless water heaters etc). Finally, power systems are to a growing extent integrated both physically though interconnections and commercially though integration of markets and agreements of cooperation. All these developments affect both the need for flexibility (value of flexibility) and the ability of the power system to provide flexibility (cost of providing flexibility).

The flexibility demands from the power system are met by generators and consumers. In the long-term perspective investments in generation, consumption and grid may all be alternative ways to address flexibility needs. Even intermittent generation may serve as a source of flexibility. Flexibility can also be delivered by electricity storage facilities and by efficiently integrating the power system too that of heat and gas, exploiting flexibility across energy carriers. 
In this report we specifically discuss the potential for exploiting flexibility from electricity demand (consumers) in the Nordic market. However, one should keep in mind that demand flexibility has to compete with flexibility from generation, grid investments, power storage and from exploiting flexibility across markets for heat, gas and power. In general efficient demand response implies that demand is price sensitive, promoting efficient pricing and efficient utilization of resources employed in the power system at all times.

In this report we first define demand flexibility, demand response and different types and properties for flexibility (Chapter 2). Then we discuss the value of flexibility across the Nordics and how the value might change during the next 10-15 years (Chapter 3 and 4). Next, we describe the cost side of demand response and what price signals the demand side face in today's power market (Chapter 5). Finally we discuss different types of measures that are relevant to promote efficient use of demand flexibility (Chapter 5) and summarize input to a Nordic strategy on demand flexibility (Chapter 6).

We have interviewed people representing TSOs, DSOs, retailers, industry organisations and consultants/ researchers in the Nordics in order to get a better understanding of the value and potential for demand flexibility and the development in this area in general. The interviewees are listed in attachment 1 . Their input has been very useful to the project. Nevertheless, all conclusions in this report are THEMAs responsibility alone. 


\section{What is demand flexibility}

In the market place demand flexibility comes in three shapes. First, consumers may find alternatives to the use of electricity creating price sensitivity that reflects a limited willingness to pay for electricity. Second, consumers may be willing to "move" loads from periods where the system has high prices to periods of low prices (load shedding), contributing to less price volatility and lower peak prices. And finally, changing loads (up or down) may help balancing generation and consumption during operation and thereby contribute to security and quality of power supply. Different types of demand may provide flexibility with different characteristics (volume, reliability, duration of load changes, response time and recovery time) to meet variations in the demand for flexibility from different markets.

\subsection{Definition of demand flexibility}

Demand flexibility can in our context be understood as a willingness to change volumes of electricity consumed for short or long periods of time as a response to market prices, price incentives in grid tariffs or other economic incentives. In this definition, the consumers' flexibility is reflected in the price sensitivity on the demand side. Changes in volumes may also be imposed on electricity consumers, but this type of flexibility is not considered in this report.

Demand response is in this report referring to the reaction (activity) from a consumer driven by different types of price signals.

The consumer may have flexibility to regulate consumption both up and down, e.g. to increase consumption to take advantage of low prices in the market or in the grid tariffs.

Providing a specific demand response comes at a cost to the provider. The value of a certain type of demand response may vary over time and between areas. The value is set by the basic market conditions of supply and demand:

- Demand for flexibility: What is the demand for flexibility in terms of volumes, reliability and characteristics such as duration, response time and recovery time? What is the willingness to pay (the price of flexibility in the market)? 
- Supply offlexibility: What is the competition like on the supply side? What is the cost for alternative providers of flexibility (generators, consumers and imports) and what type of flexibility may the different providers deliver?

\subsection{How may demand flexibility contribute to increase efficiency?}

A more active demand side may provide value to the different parts of the Nordic power system. There are two preconditions for making a given demand response able to deliver value to the power system:

- Value: The willingness to pay for flexibility has to be sufficient in order to cover the cost of providing the demand response.

- Competitiveness: The demand flexibility has to be competitive with other resources delivering similar flexibility like generators, other consumers, storage facilities and imports.

Demand flexibility can potentially add value in three areas:

- Price formation: If the demand side is inelastic, the price formation will solely depend on the generation side. More intermittent generation and an inflexible demand side may lead to more constrained situations, price volatility and peak prices in peak load periods. However, a strong power balance, investments in grid and interconnectors and more flexibility (price sensitivity) among consumers may all serve to limit price volatility and peak prices and reduce the market power of generators (SWECO, 2011).

- System services: The purpose of system services is to balance the power system by ensuring balance between supply and demand throughout the operational phase. Balancing resources are mainly delivered by generators today, but also to some large consumers provide flexibility to the power system.

- Limit investments in the regional or local grid: If peak demand is close to the capacity limit in regional or local grid, reducing peak load may postpone or limit the need to invest in new grid. Demand response may further be important to maintain security of supply e.g. to manage incidents such as power lines tripping. Demand response may thus limit the costs of fulfilling the requirements for grid security (the $n-1$ criteria). 


\subsection{Different types of demand flexibility}

The willingness to be flexible varies between different consumers and over time for each individual provider. It will also vary depending on what kind of flexibility they are to deliver. In principle there are three types of flexibility in electricity consumption:

- Shut down of energy use.

- Shift to an alternative type of energy source.

- Shift in time of energy use.

The three alternatives are illustrated in Figure 1. The two first types, shutting down or shifting to an alternative energy source, will have the same impact on power consumption - the load will be removed for a given period and overall consumption is reduced. Alternatively (type three) the load could be shifted in time. In this case total power consumption is not reduced; it is allocated differently across the time of the day (or possibly another timeframe).

Figure 1: Illustration of different types of demand flexibility

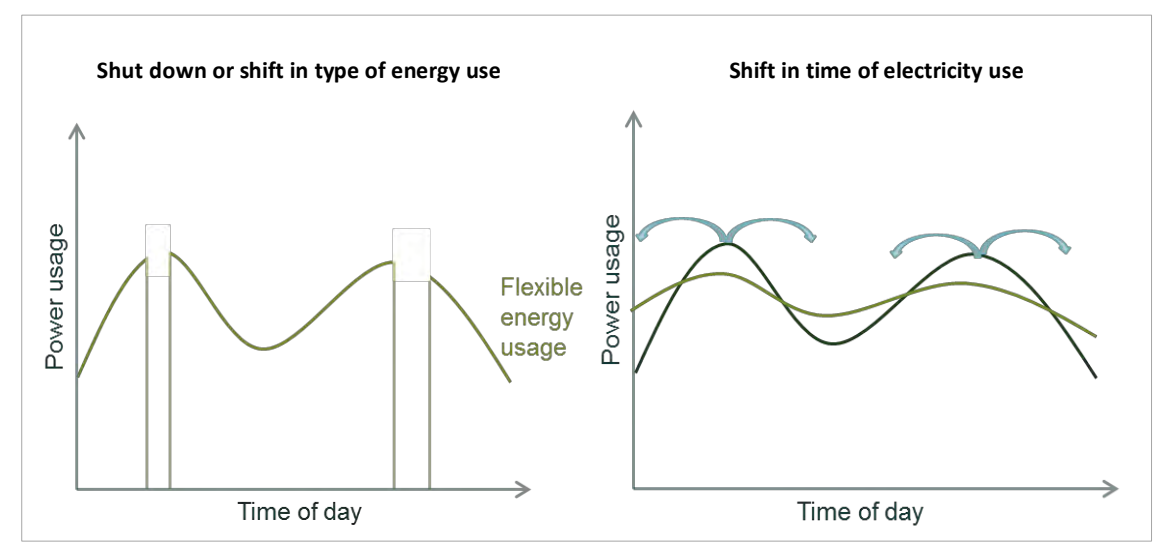

Note that the demand response may also imply increasing load during in periods of e.g. low electricity prices. In this case other energy sources may be phased out and replaced by electric (e.g. district heating switching from using gas to using electricity).

\subsection{The characteristics of demand flexibility}

The characteristics of flexibility needed in the power system are described in section 3.3. Important properties for flexibility delivered to the power system are volume, reliability and several time-related properties like duration of disconnection, response time and recovery time. Consumers are different and the type and quality of the flexibility they may provide varies. Some loads may have flexibility to disconnect for longer periods of time and for specified periods (e.g. seasons for heating or cooling), for 
certain hours during certain days of the week or they have flexibility for very short periods within the hour. Loads from industrial production processes and service buildings may not be available for downward regulation during weekends simply because they are not in operation.

Shutting down electricity consumption without alternative energy sources implies that e.g. industrial activity is reduced or completely stopped with reduced production and economic losses as a result. Such demand flexibility is therefore only relevant in extreme cases when electricity prices are exceptionally high. Demand flexibility is more relevant when there are alternative sources of energy available or it is possible to move consumption to another point in time. Characteristics of the flexibility such as response time, duration and recovery time of demand will affect the attractiveness (value) of the flexibility in the market. Loads that may shift to an alternative energy source can be disconnected instantly, for a long period of time - days, weeks or even months and may also be activated again shortly after the disconnection.

Shifting loads is limited by characteristics of the given load. For heating, cooling and ventilation the inertia will depend on how long it takes for temperature and $\mathrm{CO}_{2}$ levels to change and to what extend the consumers will accept the cost of reduced comfort. The response time of load shifting varies between providers. Possible buffers in temperature etc. may make it possible to disconnect the load without reducing the comfort levels or limiting the industrial output. Such buffers (caches) may e.g. be provided by buildings, batteries or heat storage.

Loads that are not running $24 / 7$ have limited potential for intraday flexibility. The loads may be scheduled to run at hours when electricity prices are low or outside peak hours, within the limitations that apply. For instance, green houses need to be lit most of the time, but lights can be turned off some hours per day without harming plant growth. In principle, the same logic apply to appliances as dish washers and washing machines in households, but in practice the flexibility of when to run the machines may be limited by other time restrictions. 
Table 1: Categorization of flexible loads

\begin{tabular}{|c|c|c|c|}
\hline Type of flexibility & Type of load & Example industry & Example buildings \\
\hline \multicolumn{4}{|c|}{ Shut down energy usage } \\
\hline & $\begin{array}{l}\text { Processes that may be } \\
\text { interrupted }\end{array}$ & $\begin{array}{l}\text { Stops in continuous } \\
\text { processes with reduced } \\
\text { production as a result }\end{array}$ & $\begin{array}{l}\text { Electrical equipment like } \\
\text { lightning, lifts or TVs }\end{array}$ \\
\hline \multicolumn{4}{|c|}{ Shift in type of energy source } \\
\hline & $\begin{array}{l}\text { Loads supported by } \\
\text { back-up with alterna- } \\
\text { tive energy source }\end{array}$ & $\begin{array}{l}\text { Electrical heat boilers } \\
\text { with alternative oil or } \\
\text { gas boilers }\end{array}$ & $\begin{array}{l}\text { Electrical heat boilers } \\
\text { with alternative oil or } \\
\text { gas boilers }\end{array}$ \\
\hline \multicolumn{4}{|c|}{ Shift in time of electricity usage } \\
\hline & Loads with inertia & $\begin{array}{l}\text { Processes with cooling } \\
\text { or heating }\end{array}$ & $\begin{array}{l}\text { Heating, cooling or } \\
\text { ventilation }\end{array}$ \\
\hline & $\begin{array}{l}\text { Loads or processes with } \\
\text { storage or cache }\end{array}$ & $\begin{array}{l}\text { Grounded biomass in } \\
\text { pulp and paper }\end{array}$ & $\begin{array}{l}\text { Batteries and hot water } \\
\text { tanks for tap water or } \\
\text { heating. Batteries }\end{array}$ \\
\hline & $\begin{array}{l}\text { Processes or appliances } \\
\text { with excess capacity }\end{array}$ & $\begin{array}{l}\text { Greenhouses where } \\
\text { lights may be shut down } \\
4 \text { hours per day }\end{array}$ & $\begin{array}{l}\text { Dish washers and } \\
\text { washing machines that } \\
\text { does not run } 24 / 7\end{array}$ \\
\hline
\end{tabular}





\section{Supply and demand for Flexibility in the Nordic region}

Flexibility is needed in the power system to balance the generation and consumption of electricity. This flexibility is handled through various markets. The wholesale market reflects the power balance and prices increase when there is a shortage of energy within a given time frame. The TSOs purchase different types of reserves to secure short and long term security of supply. Also DSOs provide to some degree price signals to promote demand flexibility through grid tariffs. Generation, mainly hydro power with reservoirs, provides most of the flexibility in the Nordic power system today. But also power intensive industry is active in the market, providing price sensitive bids in the wholesale market and different types of reserves for the TSOs. Heating systems in buildings is also to partly flexible if there is heat storage (in Finland) or alternative heat sources (oil burners) available.

In this chapter we describe the demand for flexibility and how the willingness to pay for different kinds of flexibility may vary across the Nordic region depending on the local characteristics the power system. We further describe how the demand for flexibility is met through market based solutions and how consumers contribute with flexibility in these solutions. The description is fairly high-level defining a starting point for discussing future developments in the supply and demand for flexibility, future challenges and the possible roles of demand response in the Nordic region.

\subsection{What defines the need for flexibility in the power system?}

The value (price) of flexibility in the market is set by the supply and demand of flexibility, as described in section 2.1. Figure 2 illustrates the balance in the power market between generation and consumption and that this balance can be composed of very different mixes of generation and load. The resources may be base load with stable and predictable (and adjustable) levels of consumption and generation, e.g. large industry and generation from nuclear plants, thermal plants and large hydro plants. Other resources may have more or less predictable fluctuations intraday or intraweek, like consumption from households and service industry. Yet other resources may be less predictable and fluctuate due 
to temperature, wind, sun and precipitation like run-of-river hydro plants, wind generation and solar panels. In the long-term both generation and consumption may fluctuate due to economic development, new technology and politics.

Figure 2: Power systems may be very different, but they always balance

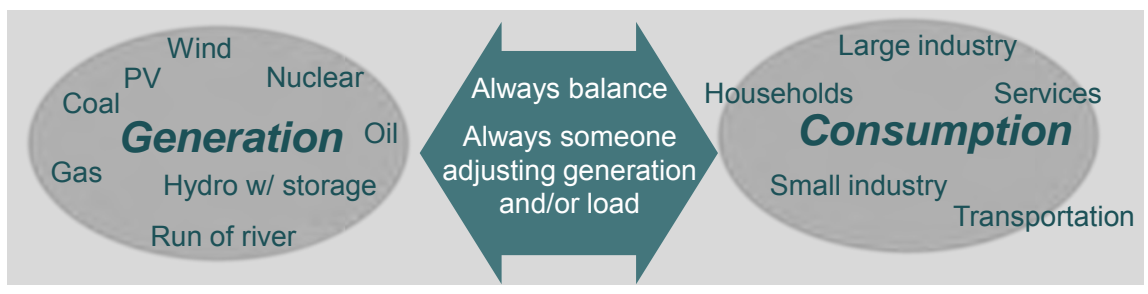

Generation and load creating the local power balance in Figure 2 may partly be located outside the area and be imported. The Nordic power system is integrated physically (interconnections), through cooperation (common system operations) and market-wise (market coupling). In spite of cooperation and integration - there is and will still be physical bottlenecks in the power system and the Nordic power system will thus be divided into areas that may have very different mixes of power generation and consumption. The demand for flexibility may thus vary significantly both in terms of volumes and types of flexibility requested across the Nordic areas. In the Nordic market bidding zones (price areas) are established to make the market reflect these differences.

An area dominated by e.g. stored hydro and large industry need flexibility to balance seasonal fluctuations in hydrology while an area dominated by wind generation and household consumers need flexibility to balance daily fluctuations in wind and consumption (e.g. challenging peak-loads).

In addition to managing more or less predictable variations in generation and load, the power system also need flexibility to manage unforeseen incidents that may provide shocks in the power system. Such incidents may include when generators trip, when large industrial loads suddenly drops or when gridlines are disconnected due to failures of some sort.

\subsection{The value of flexibility varies across the Nordic region}

Figure 3 illustrates the differences in the mix of generation and consumption across the Nordic region. The mix of generation and consumption defines the demand for flexibility. The current situation in the Nordic countries may in short be described as follows: 
Figure3:DE 3

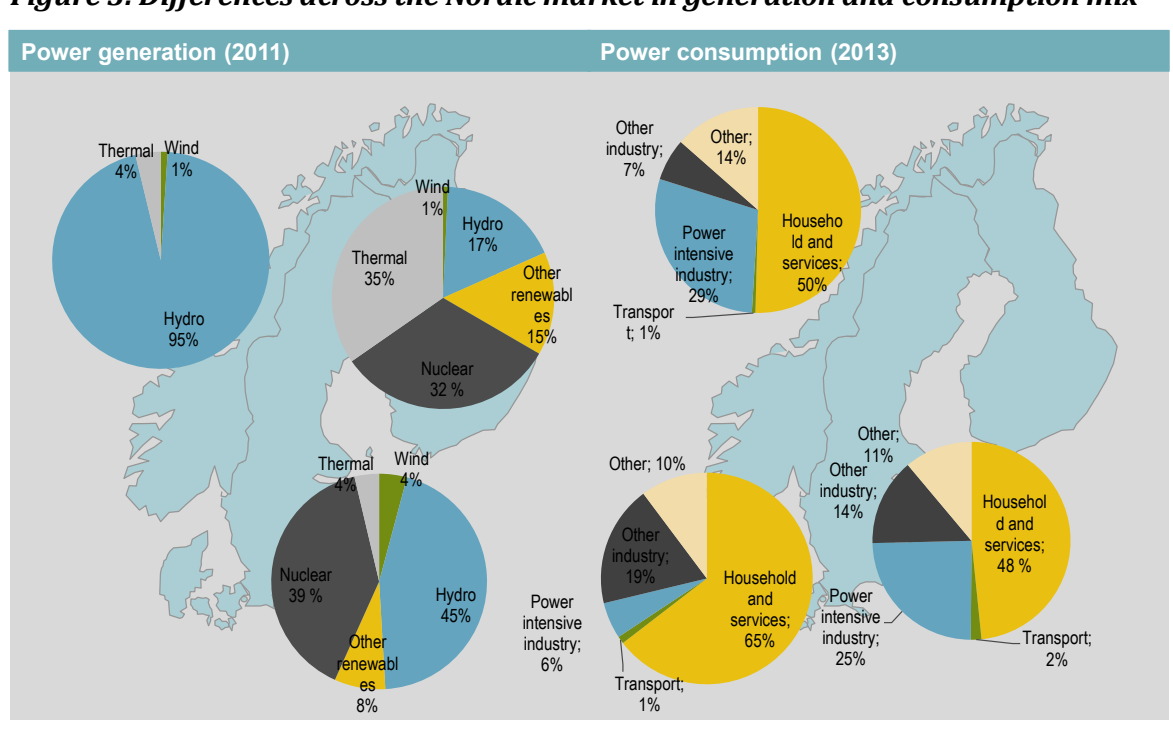

\section{Denmark}

A large share of generation is intermittent and there is no power intensive industry. Households and small industry / services do not use electricity for heating purposes and a mix of electricity, gas and heat cover their energy needs.

- Have flexibility to manage seasonal variations in consumption.

- Need flexibility to manage fluctuations in renewable generation, peak-load demand, short-term balancing of the power system and reserves to manage incidents in the power system.

\section{Finland}

A large share of generation has day/night flexibility (hydro and new coal power plants) and a significant, but falling, share of consumption is price sensitive power intensive industry. Demand response from industrial freezers is to a growing extent used as system services (frequency control). Single home buildings have water based heat storages that are currently switching heat loads from day to night. This set-up combined with hourly metering for all (97 per cent) consumers represents opportunities for further exploiting demand flexibility from small consumers.

- Have day/night flexibility, but a falling share of price intensive industry and of condensing power generation may be challenging.

- Need flexibility to manage peak-load and incidents. 


\section{Norway}

A large share of generation is flexible large hydro with reservoirs and a significant share of consumptions is price sensitive power intensive industry. Demand response from industry is to a growing degree used as system services. The hydrological balance may vary between areas. Electricity dominates as energy source for heating in households.

- Have flexibility to balance short term fluctuations in supply/demand and to manage incidents.

- Need flexibility to manage possible seasonal shortages (dry years) and surpluses in hydrological balance (periods of high inflow and low load).

\section{Sweden}

A large share of flexible hydro storage in the north and a significant share of the consumption is power intensive industry. Both generation and consumption are less flexible in the south. PII is providing more bids in markets power reserves. Electricity is the main energy source for households (approx. 60 per cent), but district heating is the main source of heating in buildings.

- Have flexibility to balance short term fluctuations in supply/demand and to manage incidents in the north.

- Need flexibility to manage seasonal variations in hydrological balance in the north and flexibility to manage peak-load challenges in the south.

\section{Nordic region}

The frequency in the synchronous Nordic area (Denmark-East, Finland, Sweden and Norway) is a regional concern, and the task of ensuring a stable frequency has become more challenging over time as illustrated in Figure 4.

- Quality of frequency is challenged by intermittent generation and of new interconnectors.

- The Nordic TSOs need short-term flexible resources in order to ensure system security and quality of supply. 


\section{FigG}

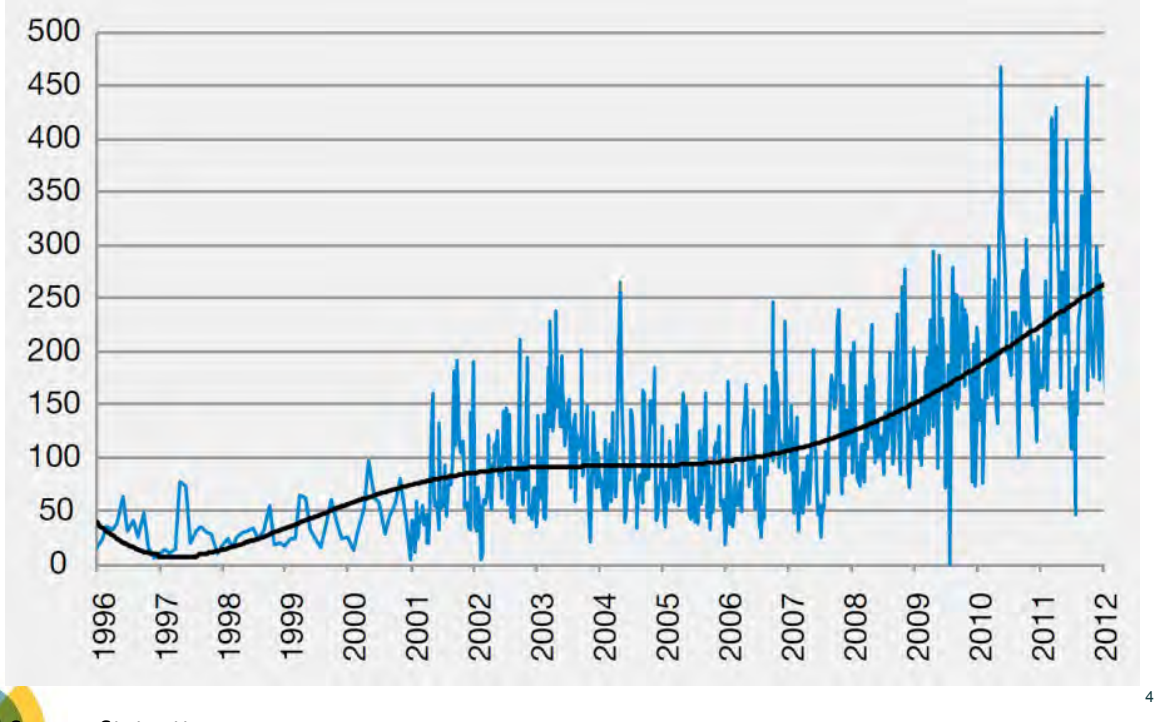

Source: Statnett.

\subsection{Meeting the demand for flexibility}

In this section we describe the market solutions and regulations that are established in order to ensure that the demand for flexibility is always met.

The value of flexibility varies across the products and over time. Flexible consumers and generators constantly have to consider "where and when" to sell flexibility. In this section we describe the how this is done, how flexibility is priced in spot markets, balancing markets and in markets for reserves.

\subsubsection{Trading of flexibility in the wholesale markets}

Table 2 provide an overview of how flexibility is addressed in the wholesale market. Flexibility is however not a product itself, but an implicit element of all trading in the wholesale market. The willingness to change volumes consumed or generated varies between market players and over time. Balance responsible parties (BRPs) connected to the highvoltage grid (generators, utilities, large industries and retailers on behalf of consumers) are nominating schedules in the day-ahead and intraday markets, and are charged for the cost of imbalances (deviations from scheduled consumption or generation). The aggregated imbalances in the power system are managed by the TSOs real-time (see 3.3.2). 
The forward market provides an opportunity to trade power for future delivery (financial), and the prices reflect future price expectations of the market players. Generators and consumers having flexibility will have incentives to consider the future price curve carefully and seek to generate when prices are high and consume when prices are low, thus limiting overall price volatility in the market. Ultimately the forward price curve would be completely flat if flexibility was abundant in the market.

Generators and consumers that have "forward-looking" flexibility (e.g. possibilities to plan a three week shut-down for maintenance or when to generate from a hydro plant with storage) can use derivatives to manage future price risk. Thus, the market provides incentives to consumers and generators on how to utilize flexibility promoting both economic efficiency and security of supply.

The generators and consumers that have flexibility place price sensitive bids/offers in Elspot or they may want to provide block-bids (condition on being activated for four consecutive hours) or to flexible one-hour bids (a bid that can be activated for only one hour during 24 hours).

Short-term flexibility may further be sold in the intraday market (Elbas) to market players that want to adjust their schedule closer to the hour of operation.

The various products traded in the wholesale market are defined by the following characteristics:

- Volume: the size of the contract in MW.

- Duration: the period for which the volume is to be generated/ consumed in hours.

- Price: there could be both an option price (price for being available).

- Energy price (price for actual energy generated/consumed).

Table 2: Possibilities to trade and hedge flexibility in the Nordic wholesale market

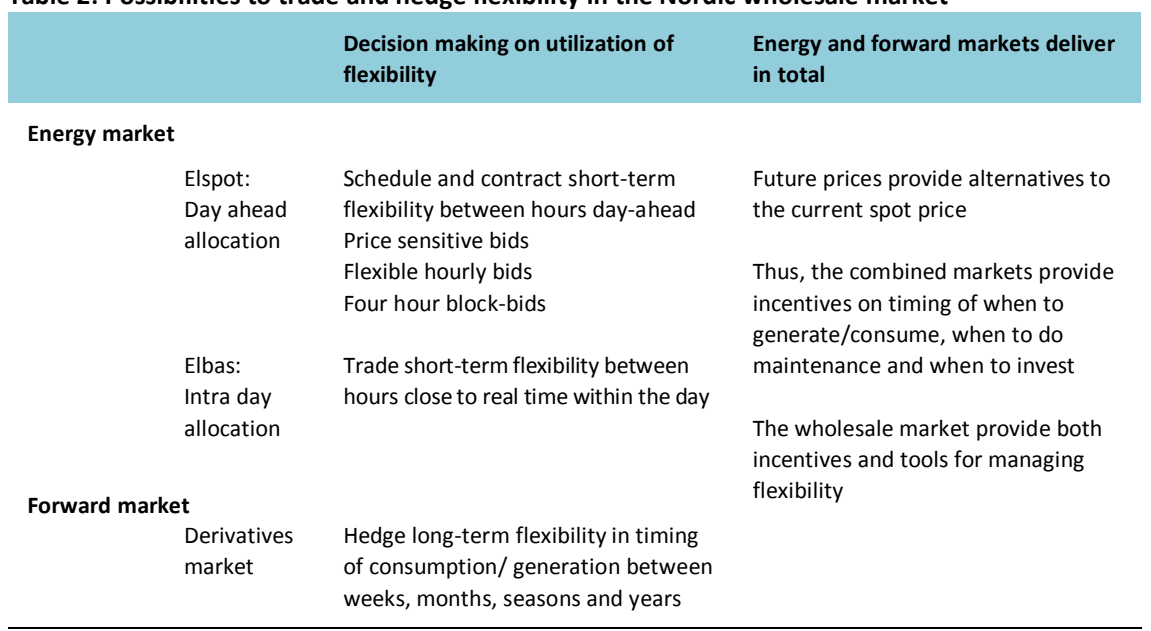


Price volatility in the spot market can be short-term (Figure 5) or longterm (Figure 6). Price volatility in the Nordic market is quite limited in the three most northern price areas in Sweden and most of Norway, however somewhat stronger in South-Sweden, Denmark and Finland. Figure 5 show the price during $13^{\text {th }}$ of January for the last four years for one price area per country. The daily price volatility during normal conditions is not sufficient to promote large volumes of demand response.

Figure 5: Examples of short term price variation (within the day) in Elspot

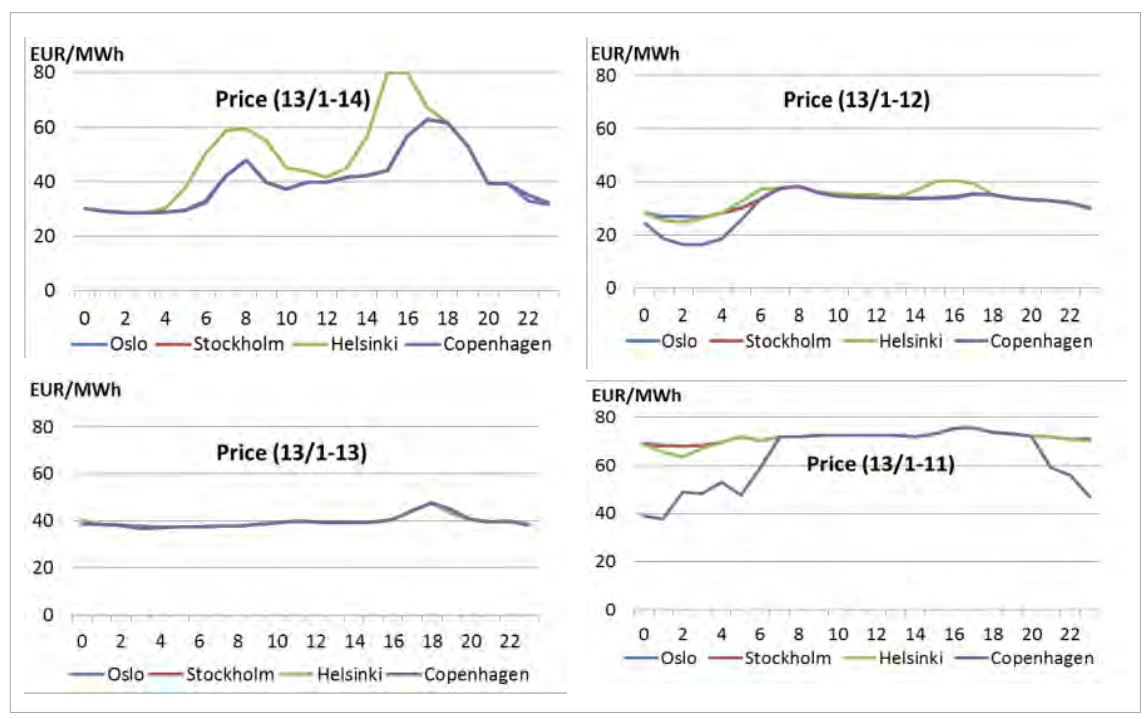

Source: NordPool spot.

Seasonal price variations are larger than intra-day volatility, often driven by the hydrological balance. Industry may however have limited ability to exploit the seasonal price differences since it will limit their core production of goods and services. In general, the price is normally higher than the system price in Finland and Denmark (price area DK2/ Copenhagen), but with some low price periods (probably caused by high generation from wind) in Denmark. The prices in Stockholm (SE3) and in Oslo (NO1) follow the system price more closely. The prices may vary from summer and winter, but also the winter/ summer prices vary over time. 


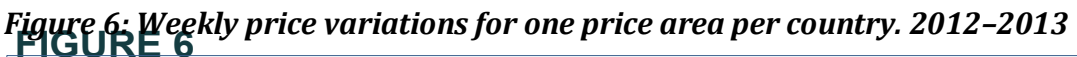

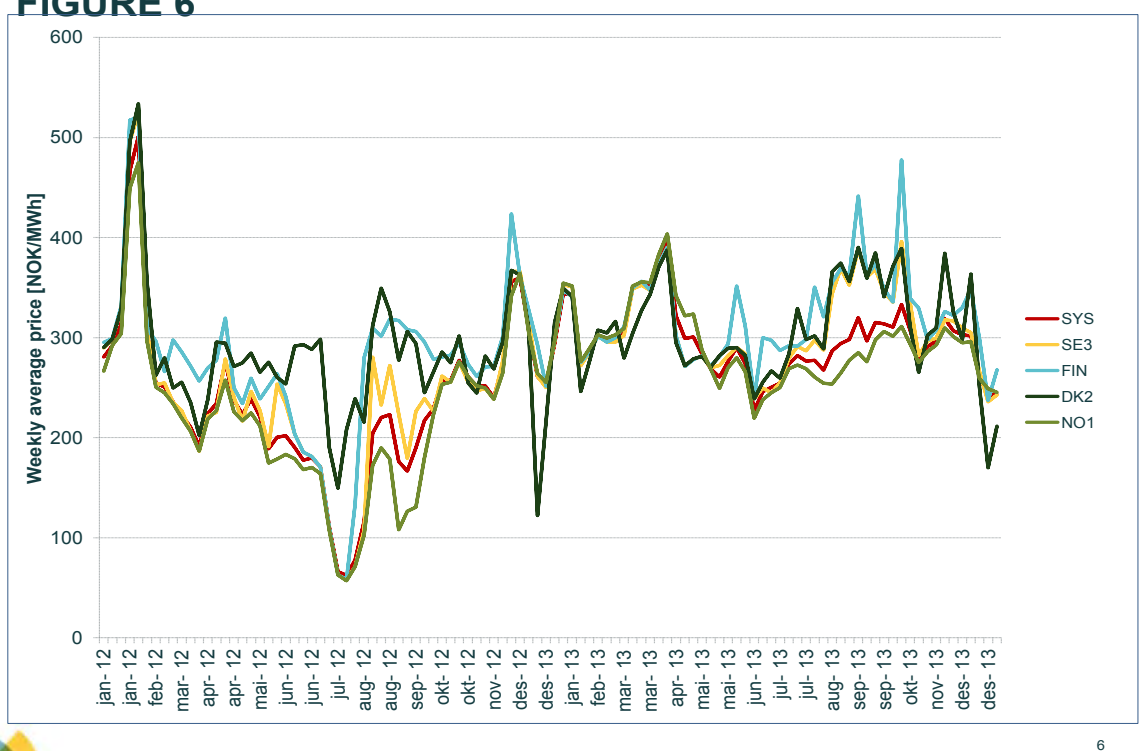

Source: NordPool spot.

\subsubsection{TSOs contracting flexibility to ensure system security and security of supply}

Table 3 provide an overview of how flexibility is addressed in the "TSOmarkets" to enable TSOs to balance the power system real-time and to promote long-term security of supply.

The schedules for the real-time operations of consumers and generators are based on power purchased and sold in the wholesale market (Elspot and Elbas). TSOs purchase reserves in the balancing market in order to manage imbalances and bottlenecks, incidents and disturbances. To this end TSOs purchase different kinds of reserves, including manual restoration reserves (FRR-M or "regulerkraft") used to manage congestions and imbalances and automatic reserves used to ensure system security (frequency) and manage imbalances.

TSOs may want to contract manual and/or automatic reserves in a long-term perspective (capacity markets), providing the TSOs with more certainty for their operations and the market players with long-term incentives to provide a specified kind of flexibility. TSOs may also purchase long-term energy reserves (guaranteed volumes in Elspot) from consumers and generators to ensure security of supply in possible future constrained situations (e.g. strategic reserves and energy options to power intensive industry). Long-term contracting promotes investments in flexibility by both providing long-term price signals and opportunities to limit risk. 
The various "TSO-products" may have features in addition to those listed in 3.3.1. In addition to price, duration and volume features may include:

- Activation period: the time period for which a volume is reserved and can be activated.

- Response time: the time it takes to activate a bid.

- Recovery time: minimum time between activations.

Table 3: TSOs purchasing flexibility in markets for reserves, balancing the power system

\begin{tabular}{|c|c|}
\hline & Decision making on utilization of flexibility \\
\hline \multicolumn{2}{|l|}{ Manual reserves } \\
\hline $\begin{array}{l}\text { Restoration } \\
\text { Reserves (FRR-M) }\end{array}$ & $\begin{array}{l}\text { Consumers/generators nominate willingness to adjust consumption } \\
\text { (or generation) within the hour } \\
\text { The TSO will contact the market player who then adjust their volumes }\end{array}$ \\
\hline $\begin{array}{l}\text { Long-term } \\
\text { reservation }\end{array}$ & $\begin{array}{l}\text { Consumers/generators commit to provide manual reserves (FRR-M) } \\
\text { in defined future periods }\end{array}$ \\
\hline & Example: the Norwegian RKOM (weekly and seasonally purchased) \\
\hline \multicolumn{2}{|l|}{ Automatic reserves } \\
\hline $\begin{array}{l}\text { Real-time } \\
\text { balancing }\end{array}$ & $\begin{array}{l}\text { Generators let TSOs automatically adjust volumes in order to manage } \\
\text { bottlenecks and safeguard the frequency }\end{array}$ \\
\hline & $\begin{array}{l}\text { Examples: Frequency Restoration Reserves (FFR-A) and Frequency } \\
\text { Containment Reserves (FCR) } \\
\text { Large consumers and generators may be automatically regulated in } \\
\text { order to manage incidents and frequency distortions ("systemvern") }\end{array}$ \\
\hline $\begin{array}{l}\text { Long-term } \\
\text { reservation }\end{array}$ & $\begin{array}{l}\text { Generators commit to provide automatic reserves (FRR-A or FCR) in } \\
\text { defined future periods } \\
\text { Example: the Danish long-term LFC auctions }\end{array}$ \\
\hline \multicolumn{2}{|l|}{ Energy reserves } \\
\hline $\begin{array}{l}\text { Long-term } \\
\text { reservation }\end{array}$ & $\begin{array}{l}\text { Consumers/generators commit to contribute to the energy balance } \\
\text { for longer periods of time in the future }\end{array}$ \\
\hline & $\begin{array}{l}\text { Examples: strategic generating reserves in Finland/Sweden and } \\
\text { energy options for large consumers in Norway }\end{array}$ \\
\hline
\end{tabular}

Figure 7 illustrates the TSO costs for system services. The cost increase from 2010 to 2013 has been more than 50 million EUR, and the TSOs expect this cost to increase further during the next years. 
Figure 7: The TSOs costs of balancing services 2010-2013. Million EUR

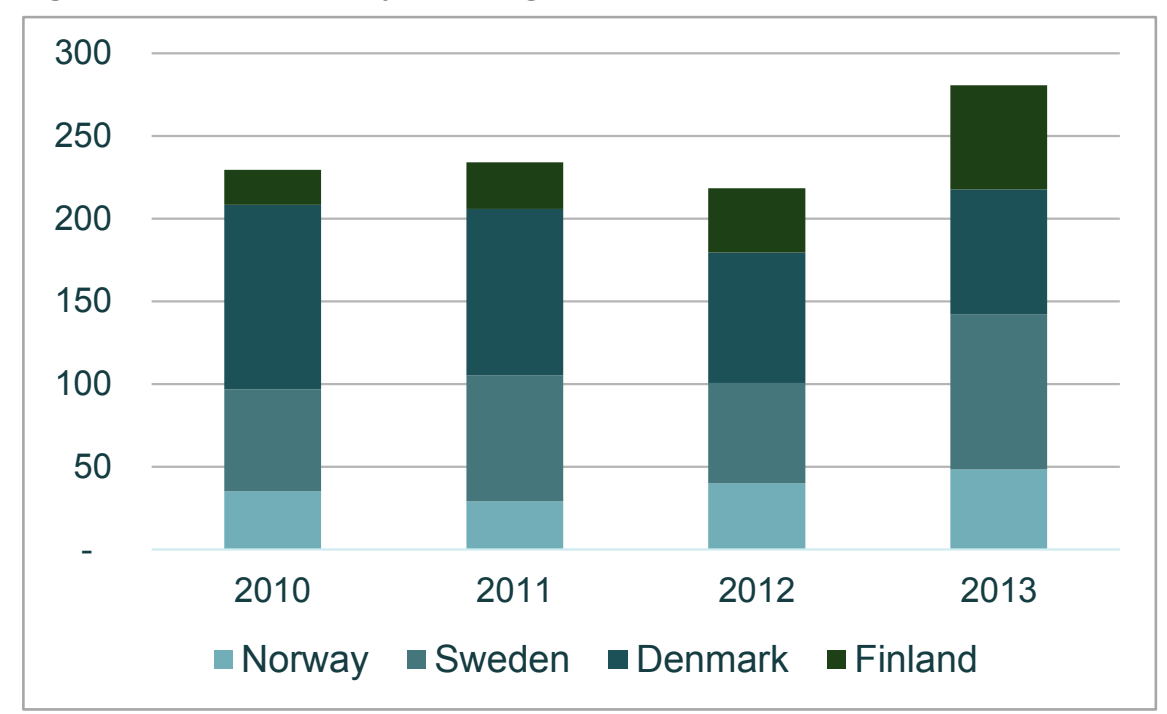

Source: energinet.dk. SvK, Fingrid, Statnett.

\subsubsection{The value of flexibility reflected in the grid tariffs}

The grid tariffs play an important role as price signals for consumers of electricity in both the short and long term. There are several grid tariff models within each country. The various tariff contracts discussed below is based of contract types offered by the largest DSOs ${ }^{1}$ in the four Nordic countries. The components in the grid tariffs, and therefore the incentives for demand flexibility, differ somewhat between large and small consumers:

\section{Small consumers}

- Hourly meters. Finland has in addition hourly meters for small consumers. Sweden introduced smart meters to all grid customers in 2009 , but the measured time frame is daily, not hourly. Dongs tariff to small consumers with smart meters include time of use tariffs for different time of day, weekdays and seasons.

- Fixed and variable tariff components. Small consumers have a twopart tariff with a variable (energy used) and fixed (yearly/monthly) component. The level of these components varies between suppliers. The energy tariff is higher that the marginal loss of the distribution.

- Time-of-use. Several grid companies in all Nordic countries offer timeof-use contracts. Norwegian and Swedish customers may choose tariff contracts where the tariff varies between seasons while they in

${ }^{1}$ Sweden: Vattenfall and E-ON, Finland: Fortum and Helsingin Energia, Denmark: Dong Energy Distribution and Norway: Hafslund Nett AS. 
Denmark and Finland offer contracts where the tariff varies due to time of day, time of week and time of year.

\section{Large consumers}

- Hourly meters. All large customers are hourly metered in the Nordic countries.

- Three-part-tariff. Large customers have a three-part tariff with a fixed part, a capacity part and an energy part. Most large customers are obliged to buy a time-of-use contract where the variable price is higher during peak load periods.

- Time-of-use. Time-of-use tariffs are mandatory for large consumers in all Nordic countries. Time or year is the most commonly used timeframe, but time of day is also in use.

- Switching energy source. In Norway and Sweden may large customers, with alternative energy sources, enjoy lower tariff if they allow the grid company to disconnect load in certain situations. The size of the tariff discount varies.

- Capacity. Sweden, Finland and Norway require large customers to have capacity based tariffs. These customers have an incentive to keep their consumption below a certain level.

Table 4: Tariffs offered to customers is based on consumption volume

\begin{tabular}{|c|c|c|c|c|}
\hline & Norway (Hafslund) & Sweden & Finland & Denmark \\
\hline Energy only & $\begin{array}{l}\text { Customers with } \\
\text { consumption below } \\
100,000 \mathrm{kWh}\end{array}$ & $\begin{array}{l}\text { Customer with main } \\
\text { fuses below } 80 \mathrm{~A} \\
\text { Customers connected } \\
\text { to the low voltage } \\
\text { grid }\end{array}$ & $\begin{array}{l}\text { Customer with main } \\
\text { fuses of } 63 \mathrm{~A} \text { and } \\
\text { below }\end{array}$ & $\begin{array}{l}\text { Customers con- } \\
\text { nected to grid with } \\
\text { voltage level } \\
\text { below } 10 \mathrm{kV}\end{array}$ \\
\hline Power & $\begin{array}{l}\text { Customers with } \\
\text { consumption above } \\
100,000 \mathrm{kWh}, 125 \mathrm{~A} \\
\text { in } 230 \mathrm{~V} \text { grid or } 80 \mathrm{~A} \\
\text { in } 400 \mathrm{~V} \text { grid }\end{array}$ & $\begin{array}{l}\text { Customers with main } \\
\text { fuses above } 80 \mathrm{~A} \text {. } \\
\text { Customers connected } \\
\text { to grid with a voltage } \\
\text { level above } 6 \mathrm{kV}\end{array}$ & $\begin{array}{l}\text { Customers with } \\
\text { main fuses above } \\
3 \times 80 \mathrm{~A} \\
>100,000 \mathrm{kWh} / \mathrm{y}\end{array}$ & No \\
\hline Time of use & $\begin{array}{l}\text { Offered to small } \\
\text { consumers with } \\
\text { consumption above a } \\
\text { certain level. } \\
\text { Seasonal time-of-use } \\
\text { is mandatory for } \\
\text { large customers } \\
\text { (consumption above } \\
100,000 \mathrm{kWh} \text { ) }\end{array}$ & $\begin{array}{l}\text { Offered to all cus- } \\
\text { tomers by some grid } \\
\text { companies. } \\
\text { Mandatory for } \\
\text { customers with main } \\
\text { fuses above } 80 \mathrm{~A}\end{array}$ & $\begin{array}{l}\text { Offered to all } \\
\text { customers. } \\
\text { Mandatory for large } \\
\text { customers }\end{array}$ & $\begin{array}{l}\text { Customers with } \\
\text { hourly metering. } \\
\text { Mandatory for } \\
\text { customers con- } \\
\text { nected to grid with } \\
\text { a voltage level of } \\
10 \mathrm{kV} \text { or higher }\end{array}$ \\
\hline $\begin{array}{l}\text { Flexible } \\
\text { loads }\end{array}$ & $\begin{array}{l}\text { Reduced tariff for } \\
\text { flexible loads (alter- } \\
\text { native fuel) }\end{array}$ & $\begin{array}{l}\text { Reduced tariff for } \\
\text { flexible loads (alter- } \\
\text { native fuel) }\end{array}$ & & \\
\hline
\end{tabular}

Sources: Dong (2014), (Vattenfall, 2014) (Helsingin Energia, 2014) (Fortum, 2014), Hafslund (2014). 


\subsection{The consumer side is partly flexible}

Generation has dominated as a provider of flexibility. In this section we describe the current contribution of consumers in providing flexibility.

\subsubsection{Power Intensive Industry}

Large industry (PII) contributes in three ways as providers of demand response:

1. Wholesale market. Power intensive industry (PII) is participating in wholesale markets (Elspot, Elbas and forward markets). PII use these markets to optimize their consumption, purchasing physical power and hedging future price risk. The cost of electricity constitutes a significant part of the overall costs to PII. Thus, the price of electricity may influence their willingness to consume electricity and operate their factories. This flexibility is visible in the wholesale market. Price sensitive bids (including flexible one-hour bids) in the spot market from PII promote competition and limits possible imbalances (if the consumer has real incentives to reduce consumption at a certain price level). In a long-term perspective is PII able to limit consumption in dry years. One example is that the Swedish power intensive industry reduced their load with $400 \mathrm{MW}$ combined during the price peaks in the winter 2009/2010. Consumption equivalent of 200 MW was activated through the "effektreserven", while the rest was activated through the spot market (NEPP, 2013).

2. Balancing markets. In the balancing market PII mainly contribute with restoration reserves both in capacity markets (RKOM) and in the daily auctions for FRR-M. PII will in most cases contribute with resources for upwards regulation (reduced consumption).

PII are to a very limited degree participating in auctions for automatic reserves, but a Nordic market for FRR-A (Load Frequency Control) that is in the process of being established may develop prices that could attract volumes from PII. PII are however providing "systemvern" as an automatic reserve - this is automatic reductions in consumption due to incidents in the power system (e.g. tripping of lines).

3. Energy reserves. PII is participating with significant volumes as energy reserves in e.g. a case of hydro storage in the Norwegian market for ENOP (Energy Options). The ENOP market is tailored to explicitly attract volumes from PII. Statnett spend for the period 2012-13 close to 30 MNOK on purchasing options to cut 555 GWh (442 MW) of industrial consumption across the country. 


\subsubsection{Buildings}

Many buildings in the Nordics have alternative heating sources such as wood-burning stoves, open fireplaces or oil/ gas heaters in addition to electricity. End-users with access to alternative heating sources have higher price sensitivity due to the opportunity to switch between energy carriers based on relative price differentials. These customers are flexible both in the short and long term perspective.

In Finland, time-of-use tariffs are commonly used. Large price variations between day and night since the 70s have given Finnish households an incentive to install the necessary equipment to move a large share of their electrical consumption from day to night. Time switch in smart meters, water based heat distribution and tanks for accumulating and storing heat makes it possible for Finnish households to utilize price differences to lower their total electricity costs (Toivonen, 2013). The possibility for Finnish households to store electricity in large water tanks makes them flexible on short-term.

Figure 8 illustrates how Finnish households with electric heating utilize their flexibility by moving their electricity demand from day to night. Residential buildings without electric heating have a normal load profile, with their largest demand during daytime.

FIGURE 8

Figure 8: Load profile of residential customers in Finland

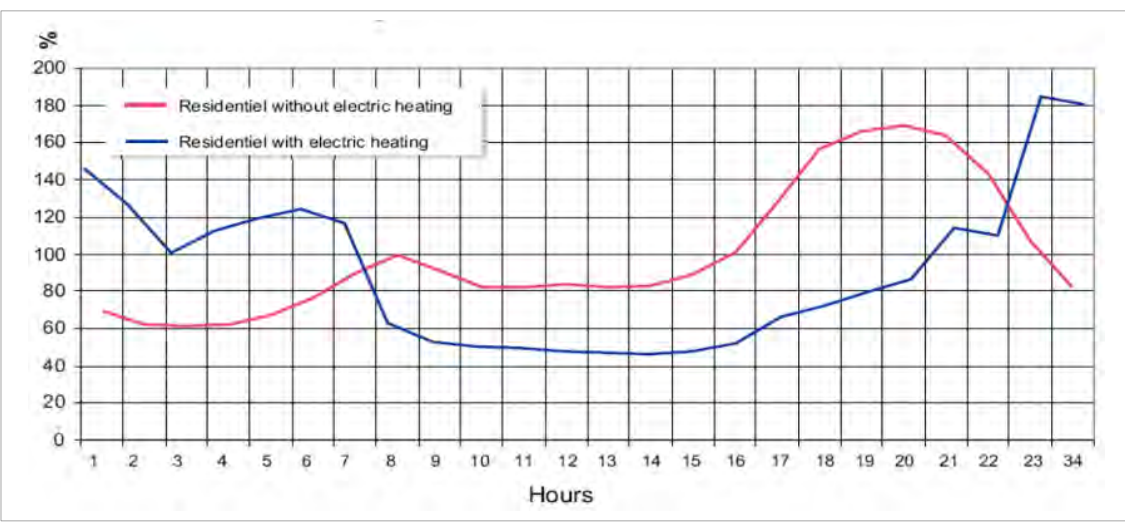

Source: VTT (2007).

In Norwaray, Thayfrgeuticusistomer with annual electricity consumption above $100000 \mathrm{kWh}$ pay a grid tariff based on their energy and capacity usage. There are service providers helping municipalities and property companies to optimize their energy usage, both by reducing the overall level of energy consumed, but also to reduce the costs of the energy used. Avoiding power limits in the grid tariff is their main economic motivation to shift loads in time. 



\section{Both demand and supply of flexibility is changing}

More intermittent generation in combination with increasing numbers of electrical vehicles and the phase out of oil burners is by many considered as clear signs that the value of demand flexibility is increasing. We do not fully agree, and argue that the future value of demand flexibility in fact is uncertain and not fully understood as there are changes in the Nordic power system affecting the value of demand flexibility in opposite directions. Some examples of developments that may decrease the future value of demand flexibility are i) a positive power balance that will reduce the risk of energy scarcity and high peak prices, ii) increasing transmission capacity between price areas that will both further reduce the risk of local price peaks and make existing flexibility (reserves) available in a larger geographical area and iii) increased energy efficiency in new and existing buildings and industry that may limit peak loads at the DSO level.

The most common demand response is reduction of loads for a given period of time. As a result of a positive power balance in the Nordic market the next 10 years combined with an increased share of intermittent wind generation, spot prices may be very low, or even negative, at times. The most relevant demand response for some consumers (i.e district heating) will therefore be to switch from other energy sources to electricity during low price periods and thereby increase their electricity consumption.

In Chapter 3 we describe the current solutions for meeting the demand for flexibility in the power system. Policy makers, investors and market parties have to both understand this picture and alternative future developments when they make strategies and plans for the future. In this chapter we discuss changes in the Nordic power system that will influence the future value of demand flexibility. It is not within the limits of this project to assess the implications of all future developments of the Nordic power system, the discussion is therefore at a high-level. To get a clear understanding of how developments influence the total value of demand flexibility, further assessments are necessary. 


\subsection{Summary of main uncertainties and developments}

Table 5 sums up our discussion on expected developments and the effects both on the power system/market in general and on the supply/demand for flexibility. There is significant uncertainty both related to the magnitude and timing of the developments and of the effects these developments may have on the power system, the power market and on the demand/supply of flexibility.

Table 5: Summary of possible changes in the value of flexibility

\begin{tabular}{|c|c|c|}
\hline Possible developments & $\begin{array}{l}\text { Possible effects on power } \\
\text { system and power market }\end{array}$ & $\begin{array}{l}\text { Possible effects on supply and } \\
\text { demand of flexibility }\end{array}$ \\
\hline \multicolumn{3}{|l|}{ Power generation } \\
\hline $\begin{array}{l}\text { Increased share of intermit- } \\
\text { tent power generation }\end{array}$ & $\begin{array}{l}\text { More intraday and intra-week } \\
\text { price volatility }\end{array}$ & $\begin{array}{l}\text { Increased price signal for } \\
\text { intraday flexibility }\end{array}$ \\
\hline $\begin{array}{l}\text { Power surplus in the Nordic } \\
\text { region }\end{array}$ & $\begin{array}{l}\text { Downward pressure on price } \\
\text { (possibly negative prices) }\end{array}$ & $\begin{array}{l}\text { Incentive to increase con- } \\
\text { sumption }\end{array}$ \\
\hline Small scale and at DSO-level & More complex distribution & Balancing at DSO level? \\
\hline \multicolumn{3}{|l|}{ Transmission and inter-connectors } \\
\hline $\begin{array}{l}\text { More capacity between bidding } \\
\text { zones }\end{array}$ & Less congestions & $\begin{array}{l}\text { More exchange of flexibility } \\
\text { Reduced risk of high peak- } \\
\text { prices }\end{array}$ \\
\hline $\begin{array}{l}\text { Interconnection to Continental } \\
\text { Europe }\end{array}$ & $\begin{array}{l}\text { More intraday price volatility } \\
\text { Less seasonal price volatility }\end{array}$ & $\begin{array}{l}\text { Increased price signal for } \\
\text { intraday flexibility, reduced } \\
\text { risk for high peak prices }\end{array}$ \\
\hline \multicolumn{3}{|l|}{ Infrastructure at DSO level } \\
\hline $\begin{array}{l}\text { New feed-in of intermittent } \\
\text { generation at DSO-level }\end{array}$ & $\begin{array}{l}\text { More complexity of operation on } \\
\text { DSO level }\end{array}$ & $\begin{array}{l}\text { Need for balancing on DSO } \\
\text { level? }\end{array}$ \\
\hline Heavy investments in DSO grid & Increased capacity & $\begin{array}{l}\text { Decreased value of reductions } \\
\text { in peak load }\end{array}$ \\
\hline $\begin{array}{l}\text { Smart Grid - measuring, surveil- } \\
\text { lance, control }\end{array}$ & $\begin{array}{l}\text { More accurate data on loads and } \\
\text { flows }\end{array}$ & Uncertain \\
\hline \multicolumn{3}{|l|}{ Consumption in buildings } \\
\hline $\begin{array}{l}\text { Increased use of appliances with } \\
\text { high power demand }\end{array}$ & Increased peak load & $\begin{array}{l}\text { Increased demand for flexibil- } \\
\text { ity at DSO level }\end{array}$ \\
\hline Phase out of oil burners & $\begin{array}{l}\text { Reductions in flexible loads with } \\
\text { long duration at DSO level }\end{array}$ & Reduced potential for flexibility \\
\hline Energy efficiency & $\begin{array}{l}\text { Price sensitive volumes reduced } \\
\text { (heating) }\end{array}$ & Reduced potential for flexibility \\
\hline & $\begin{array}{l}\text { Energy management systems on } \\
\text { a large scale }\end{array}$ & $\begin{array}{l}\text { Possibility for more small scale } \\
\text { flexibility }\end{array}$ \\
\hline \multicolumn{3}{|l|}{ Consumption in industry } \\
\hline Less large industry & $\begin{array}{l}\text { Less price sensitive bids and } \\
\text { system services from today's } \\
\text { consumers }\end{array}$ & $\begin{array}{l}\text { Increased demand for flexibil- } \\
\text { ity from other sources }\end{array}$ \\
\hline \multicolumn{3}{|l|}{ Market solution and regulation } \\
\hline $\begin{array}{l}\text { Harmonisation and integration } \\
\text { of markets }\end{array}$ & $\begin{array}{l}\text { More efficient market solutions } \\
\text { Flexibility available in a larger } \\
\text { market }\end{array}$ & $\begin{array}{l}\text { Increased competition } \\
\text { Business opportunities to } \\
\text { providers of flexibility }\end{array}$ \\
\hline
\end{tabular}


There are uncertainties related to how the willingness to pay for flexibility will develop during these developments. Each of the developments listed will individually have an impact on the willingness to pay for flexibility, but what will the aggregated effect of all developments be and how fast will various developments take place? Further, how will the developments affect the willingness to pay for the different types of flexibility, such as peak-load, system services, capacity for periods of energy shortage etc.?

In sum we assume the following developments and uncertainties to be important for the development in supply and demand for flexibility:

- Variations in spot price (price volatility) will probably increase due to more intermittent generation in the system. Variations in generation, and the influence on power prices, will be seasonal for run-of-river hydro power and seasonally/ weekly/ daily for wind generation. Increased capacity between the Nordics and other European countries will increase intraday volatility. Investments in transmission and a positive power balance within the Nordics will on the other hand decrease the volatility within each bidding zone. Hence, both the level and the duration of price variations are uncertain.

- Some volumes that participate in the markets for system services will be taken out of the market (mainly due to reductions in consumption from PII). This indicates that the competition in these markets will be reduced and the value (willingness to pay) may increase. On the other hand, we expect the same resources for flexibility to be utilized over a greater geographical area when new market solutions and new interconnections are in place. Thus, there is uncertainty on how the competitiveness and the willingness to pay for system services will develop.

- In general the capacity in grid at the DSO level is sufficient (based on interviews made in this project). However, there is a risk that peak loads and voltage disturbances may increase if/ when new appliances with high power loads are introduced. Increasing levels of demand response based on price volatility in the spot price may in itself increase the peak load in local grids. This may in particular be the case in Finland where much of the electricity demand for heating may cause problems for the local grid in areas with a high share of single home buildings. On the other hand, there is also uncertainty about how close to the capacity limit todays peak load is. Introducing tools for measuring the actual load (smart meters and other Smart Grid components) will reveal the actual situation. Hence, the actual relevance of reducing peak loads is uncertain and should be looked into in more detail when more data is available. 


\subsection{Changes in generation}

New generation technologies have very different characteristics compared to the "old" plants and the new plants are located in new geographical areas and sometimes at lower grid levels.

\subsubsection{More intermittent generation}

Three trends contribute to less flexibility in Nordic power generation: there will be more intermittent generation, less flexible thermal generation and a stronger power balance (surplus in a year with normal precipitation).

Power generation from wind, intermittent hydro and nuclear will increase in the Nordic countries. In Sweden and Norway is the electricity certificate system likely to foster investments of 26.4 TWh new renewable generation, mainly in wind but also some run-of river and bioenergy. Tender processes for new wind power in Denmark and feed-in tariffs in Finland will further add to the growth in Nordic renewable power generation towards 2020. Generation from different technologies in 2012 and estimated production in 2020 is shown in Table 6.

Table 6: Generation per technology in 2012 and estimated for 2020

\begin{tabular}{lrrr} 
& $\mathbf{2 0 1 2}$ & $\mathbf{2 0 2 0}$ & Change \\
Wind & & 53 & $212 \%$ \\
Hydro & 17 & 215 & $8 \%$ \\
Other renewables & 200 & 28 & $17 \%$ \\
Nuclear & 24 & 99 & $24 \%$ \\
Thermal & 80 & 46 & $-18 \%$ \\
Sum & 56 & 441 & $17 \%$ \\
\hline
\end{tabular}

Fossil fuelled generation is price sensitive and able to adjust output in line with seasonal demand. Intermittent plants do however generate when there is wind, sun and running water. Typically yearly generation profiles are illustrated in Figure 9. Intermittent hydro has a distinct seasonal profile with the peak inflow in the spring when snow is melting in the mountains. Wind generation have string weekly variations, and to some extent seasonal variations (in general more wind in the winter time). 


\section{FigURRE Example of yearly generation profiles}

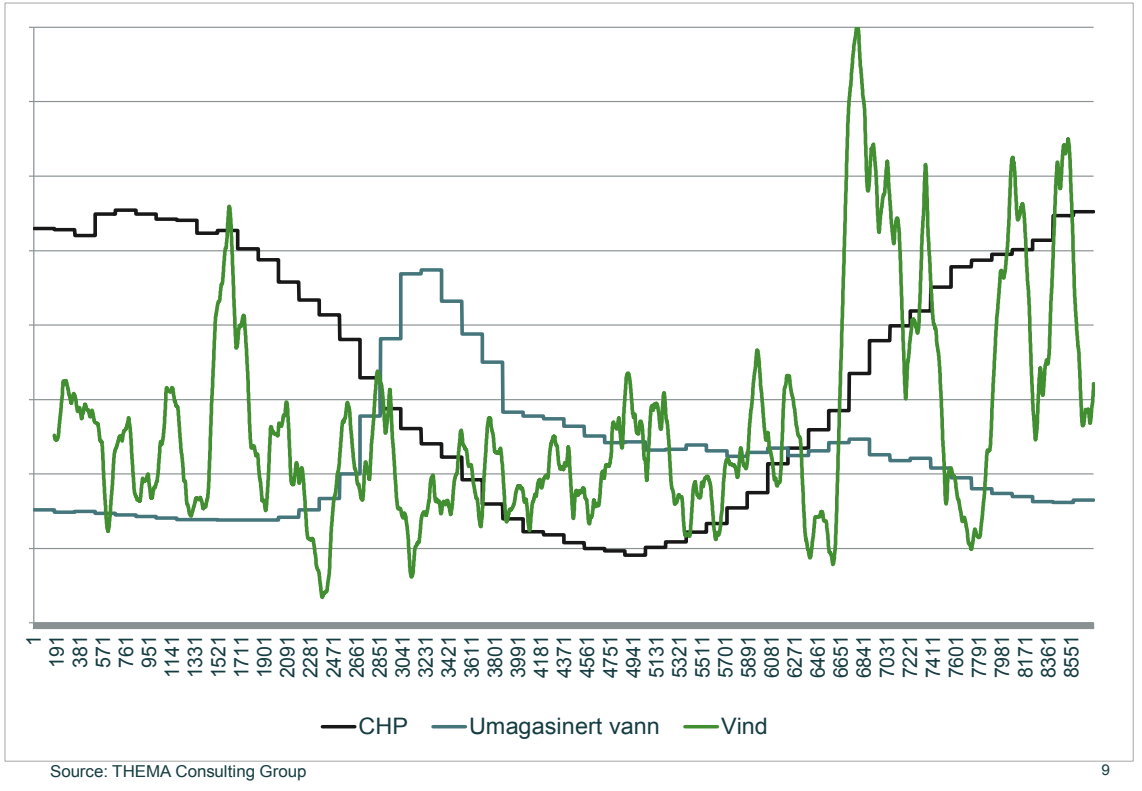

Source: THEMA Consulting Group.

Finland has a substantial share of condensing power plants that are reaching the end of their economic life time before 2020. This resource, in combination with hydro power, is the main source of flexibility in Finland. Fingrid (2014) expects the capacity in condensing power plants to be reduced from $3200 \mathrm{MW}$ in 2013 to $1500 \mathrm{MW}$ in 2020 .

We expect a substantial positive Nordic power balance in 2020 due to the investments in renewable power.

The changes in Nordic power generation will individually and all together influence the value of different kinds of flexibility:

- Surplus of power will reduce the risk of energy shortage, limiting the risk of high peak prices, and possibly leading to low and negative prices in certain periods.

- Power surplus and low electricity prices may increase electricity consumption and create peak load challenges in local grids.

- Price volatility will increase with more intermittent generation providing incentives to deliver flexibility.

- Duration of price differences may increase - periods of high/ low generation from wind may last several days.

- Demand for intra-day trade and/ or balancing services may increase in order to manage intermittency. 


\subsubsection{Generation in new geographical areas}

Thermal plants in Denmark, Sweden and Finland are located close to cities with high demand for electricity (and also heat). Norwegian hydro power was built to supply power intensive industry and where located close to the industrial sites.

Intermittent hydro and wind are however located where there is water and wind, and the plants generate electricity whenever there the water runs and the wind blows. The location of generation may be far from consumers and the pattern of the generation may deviate substantially from that of the consumers. The high increase of intermittent hydro and wind generation in the Nordic countries will thus put strain on the transmission grid and increase the need for grid enforcements.

Traditionally power has been generated in large facilities and transported from the generators via high-voltage transmission grid and into local grid to be delivered to the consumers. The distribution grid has connected the transmission grid and the consumer. Intermittent, small scale power generation from run of rivers, wind and solar panels are more often connected at lower grid levels and thereby increasing the strain on local grids. This will induce investments also at lower grid levels and is increasing the complexity of grid operation at this level. At the DSO level there are no system services to help balance the system and to means of congestion management. Increasing complexity at the DSO level may in theory create a demand for introducing system services at lower grid levels. This will then create a local market for flexibility, both from consumers and generators that are connected to the local grid. At lower grid levels, the volumes needed to handle disturbances and limitation in grid capacity will be smaller than at the TSO level. Hence, the demand side may be more relevant for delivering system services at DSO level. However, we do not see any development towards balancing markets at the DSO level, and do not see this as likely during the next 10 years.

\subsection{Changes in consumption}

There are two major trends in energy consumption in Europe serving to limiting the flexibility of consumers, increasing the cost of flexibility and potentially also increasing the risk of peak load challenges. First, the price sensitive consumption from PII is reduced and second, there is less use of fossil fuels in buildings. New services and price sensitive households may however counter some of this development. 


\subsubsection{Industrial consumption}

Due to the financial crisis, the electricity consumption from industry in the Nordic countries has been reduced the last 5-6 years. The reduction has been most evident in the Finnish forest industry (Figure 10). Fingrid (2013) states that the flexibility on the demand side is reduced due to reduced consumption in this sector.

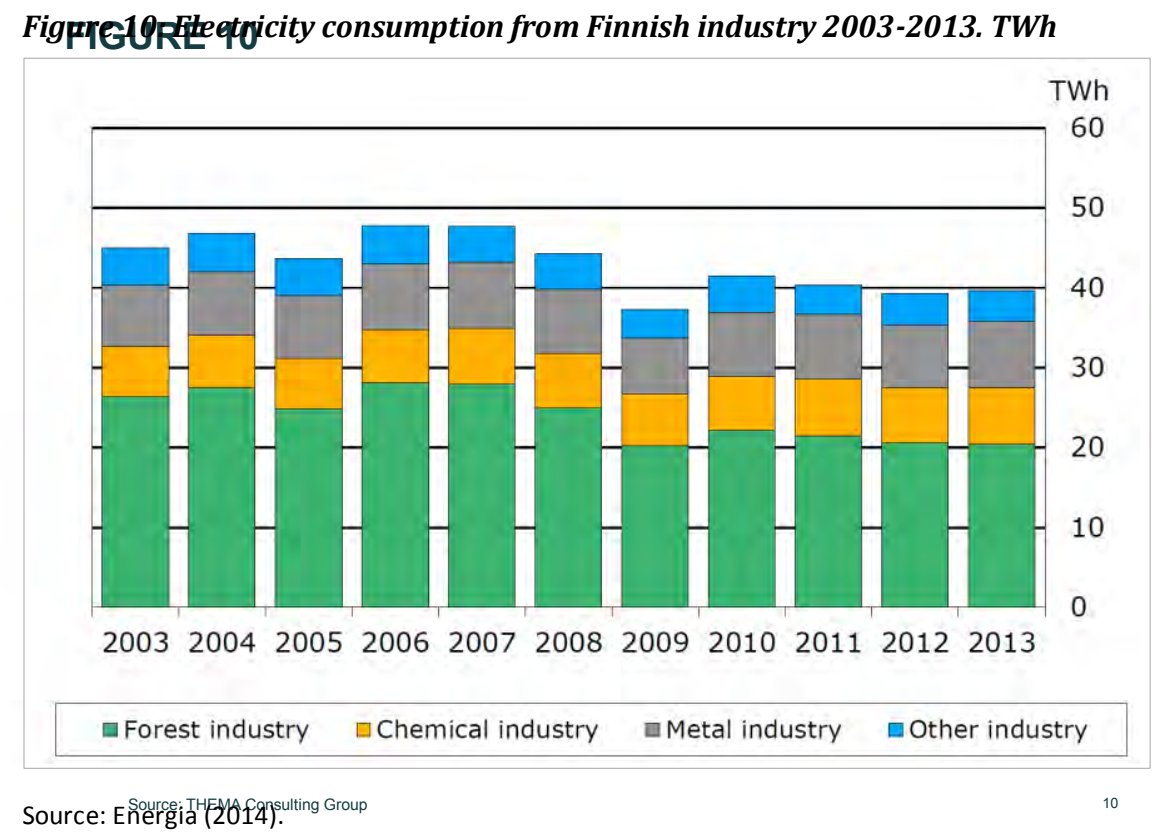

PII constitutes a significant part of consumption in Norway and Sweden. Consumption from forest industry has also been reduced in Norway over the last few years. PII is exposed to global markets and global competition and there is a continuous risk of closures and fluctuations in the levels of consumption.

Reductions in power consumption from PII may be partly replaced by new demand from district heating. Electricity consumption from district heating is highly price sensitive, will likely exploit periods of low (or negative) electricity prices and substitute other energy sources with electricity.

In Denmark there are currently 4 TWh of energy delivered from rural gas fired CHP plants. The gas fired CHP plants are no longer economically viable due to a combination of too high gas prices, too low power prices, less hours of operation due to the growth in renewables and due to regulatory changes. The owners are considering ways to replace the gas fired CHP plants and a report from Dansk Energi (2013) indicates that large heat pumps supporting district heating may be the way forward post 2020. Klimakomissionen came to a similar conclusion in 2010 suggesting that heat pumps may represent a source of flexible electricity usage if they are connected to large heat accumulation tanks. 
A similar increased use of electricity in district heating can be observed in Norway, both as base load from heat pumps and as a flexible middleand top load. According to Norsk Energi and THEMA (2013), 10-15 percent of district heating was produced in electric boilers the last few years (from an installed capacity of $400 \mathrm{MW}$ ). Most electric boilers have flexible grid tariffs, which mean that the grid company can disconnect them on a short notice if needed. A flexible connection (tariff) is often required from a commercial perspective. For the 10 largest district heating plants in Norway, 73 percent of the installed capacity are heat pumps (31 MW power input) that may be disconnected by the grid companies.

PII represents the most flexible consumption in the system. Reductions in of the consumption of PII may increase the value of flexibility in the power system, especially for system services. Increased value of system services (or costs for the TSO) will increase the pressure for adjusting product definitions in the balancing markets in order to attract more volumes (increase liquidity).

\subsubsection{Changes in energy use in buildings}

There are three main trends that may change the electricity usage from buildings:

- Increased energy efficiency may increase or decrease the peak load depending on how energy efficiency is implemented.

- Phase out of oil burners used for heating will reduce price sensitivity from buildings that may switch between using electric and oil burners today. Replacing oil burners with electric heating (included heat pumps) adds to peak load challenges.

- New electric appliances with high power usage may increase peak loads. Some appliances may also cause voltage disturbance in the local grid.

Energy efficiency may reduce both energy usage and peak load from new and refurbished buildings. The energy consumption will be reduced due to both more efficient appliances and a reduced need for heat in better isolated and refurbished buildings. This development is illustrated in the left figure below.

For some changes on the demand side, there is a substantial risk that the peak load increases even if the electricity consumption is reduced (which means the load factor is reduced). This is illustrated on the right figure below. 
Figure 11: Energy efficiency may increase or decrease the peak load

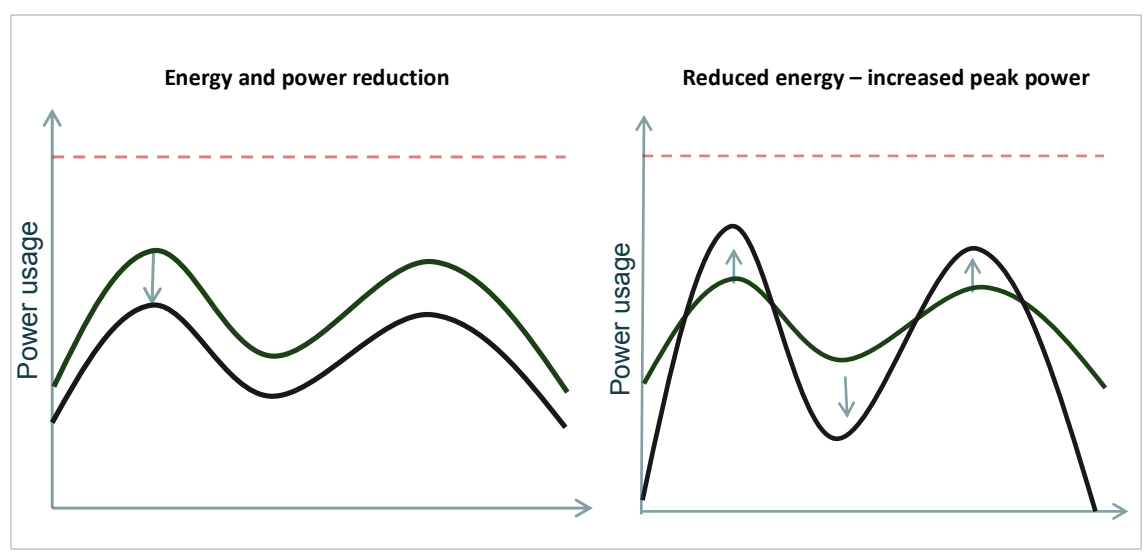

One way to reduce energy usage is to reduce storage of heat and thereby reduce the heat loss. Reduced night temperatures in buildings will increase energy efficiency, but will increase the need for power to quickly increase the temperature in the morning and thereby increase the peak load. The same logic applies for tank less water heaters. If you remove the water tank you remove the heat loss and thereby increase energy efficiency - this is the argument for the EU ban for hot water tanks. But if most showering occurs during the hours of peak load, the peak will increase if tank less water heaters are introduces in the Nordic market. The power needed in a tank less water heater might be ten times higher than one with tank (NVE, 2014). Hence the peak power from an electrically heated villa that removes the water tank might be doubled from today's level, even for villas with electrical heating. The potential for demand response from a tank less water heater is also more difficult to obtain, sine this require changing the time people shower.

Support schemes and incentives are established to limit the use of oil burners. The question is what will replace them. High taxes on electricity (in Denmark and Sweden) may reduce the likelihood of electric heating to replacing oil burners, or it might be partly restricted by regulation (for new buildings in Norway). Heat pumps and biofuel is thus more likely to replace oil burners. Even though heat pumps are energy efficient, the use of heat pumps will increase power loads when replacing oil burners. This is particularly important if air based heat pumps are preferred. During the coldest days, the air based heat pumps will not be efficient, and it is likely that additional (electrical) heat will be necessary. 
A broad introduction of products with a high power outlet may also cause problems for the power system. Loading of electrical cars (EVs) and induction cook tops are two examples. The power needed to load an EV varies between different cars and charges, the range is $2-22 \mathrm{~kW}$ (Grønn Bil, 2013). A transformation attached to the charger may reduce the power outlet substantially. The number of $\mathrm{EV}$ is increasing rapidly in Norway, but the growth is slow in Sweden, Finland and Denmark where the economic incentives for buying EVs are weaker.

Large power loads with rapid load changes may also increase power disturbances in the distribution grids and thereby increase the need for demand response or other means of correcting disturbances (SINTEF, 2012).

The changes in electricity consumption in buildings may lead to:

- Increased or decreased peak demand from building - and therefore increase/ decrease the value of flexibility to reduce peak loads in the local grid.

- Energy efficiency may increase cost of flexibility and thus limit the competitiveness of building as a flexibility provider.

\subsubsection{Will new services increase the price sensitivity in households?}

Technology and services enabling demand response from consumers is still not commonly used in the Nordic market. We therefore first describe potential types of services in general before we include a short description of services currently offered in the Nordic market.

Services may include information services, optimisation services (portfolio management) and physical management of loads (and generation):

- Information services: Service providers offer a wide range of information services from ad-hoc advice on the phone to advanced web-based solutions where customers follow the market development and the development of their own portfolio. Market monitoring may include automatic or manual warnings when prices moves or when certain incidents happens or when e.g. switching to another energy sources is profitable.

- Portfolio management services: Service providers may also offer wide range of different portfolio optimization services. Customers may buy and sell energy with the service provider, either online or on the phone, the service provider may just provide advice to the customer or the service provider may have a mandate to optimize the portfolio on behalf of the client (e.g. manage the whole decision making process of demand responses as shown in Figure 15). Services tailored specifically towards demand response may involve collecting 
relevant external data like weather reports, evaluating portfolio flexibility, calculate costs and activate bids and offers in the market. A service provider may also provide a service driven by comfort levels (e.g. maintaining 20 degrees indoor temperature) as opposed to "selling electricity."

- Physical power management: This service includes the physical nomination of loads (and generation) in spot- and intraday markets and the activation of demand response for selling flexibility in balancing markets or minimizing imbalances for balance responsible parties. Service providers may aggregate loads from several customers in order to meet minimum volume requirements for selling demand response in balancing markets.

We distinguish between individual services where the service provider manage the position of one client and aggregator services where positions of several clients are aggregated and managed by the service provider as one position. A given client may want both individual services for parts of the portfolio and in addition participate in an aggregated service for other parts of the portfolio.

New technology and services to help customers save electricity are being offered to Nordic consumers. Most products control consumption based on expected energy demand (due to weather forecasts) and prices (spot price and/or time-of-use grid tariffs). The Finnish energy companies, Fortum and Helsinki Energia, have e.g. introduced products that optimize electricity used for heating water in heat storage tanks used for space heating in single homes. The products are still new (introduced in 2014) and the market penetration is yet limited.

The Norwegian Lyse Energi has developed a similar product called Smartly. Smartly includes automatic control of heating, lighting, intruder and fire alarms. This product will be offered to customers as hourly metering is rolled out in Lyses grid area, but still only a limited share of consumers have smart meters.

The service provider Ngenic has developed a cloud-based heating control system for Swedish households. The technology intends to optimize the customer's comfort and energy use based on sensor data, weather forecast, building dynamics, energy prices, grid load and behavioral patterns.

There are also international players offering products that may be expanded to facilitate demand responses. Nest (a company recently bought by Google) offers a "smart thermostat" that will learn from your living patterns and adjust energy usage accordingly. The Nest thermometer can also be used to curb power consumption during peak hours. This demand 
response service is currently offered only to customers of a handful of utilities which cooperates with Google (wired.com). Apple announced early June 2014 a new service called HomeKit that aim to facilitate home automation. The service does not include any hardware but may work as a communication hub and standard for home automation appliances. In the same manner as iTunes store serve as a market place for apps developed by others, HomeKit will provide a market place for home automation hardware. The success of this service is therefore dependent on both user acceptance and companies to develop home automation devices prepared to use the HomeKit platform (techcrunch.com).

The main selling point for energy related home automation devices may be the money saved, but also the aspect of environmental friendliness or the customer empowerment in itself. For all demand response products currently offered in the Nordic markets, it is still early to predict how this market will develop and what influence it will have on price sensitivity and demand flexibility in households.

\subsection{Changes in infrastructure}

\subsubsection{High investments in the Nordic grid and interconnectors}

The Nordic countries plan considerable investments in both transmission and distribution. These investments will limit congestions, increase trade between areas and reduce price differences across the Nordic region and thereby serve as an alternative to demand flexibility.

\section{Transmission and interconnectors}

The Nordic region is integrated internally and with adjacent regions with interconnections as shown in Figure 12. Still do we experience bottlenecks in the transmission system and power prices may vary significantly both within and between countries. Each TSO decides on the bidding zone structure. The number of bidding zones in Norway may vary over time (dynamic bidding zones), but today there are five bidding areas. Eastern and Western Denmark are two bidding areas and since November 2011 have Sweden been split in four bidding zones. Finland is one bidding zone. 


\section{FIGURE 11}

Figure 12: Shares of congestion hours between neighboring price areas and maximum transmission capacities in 2012

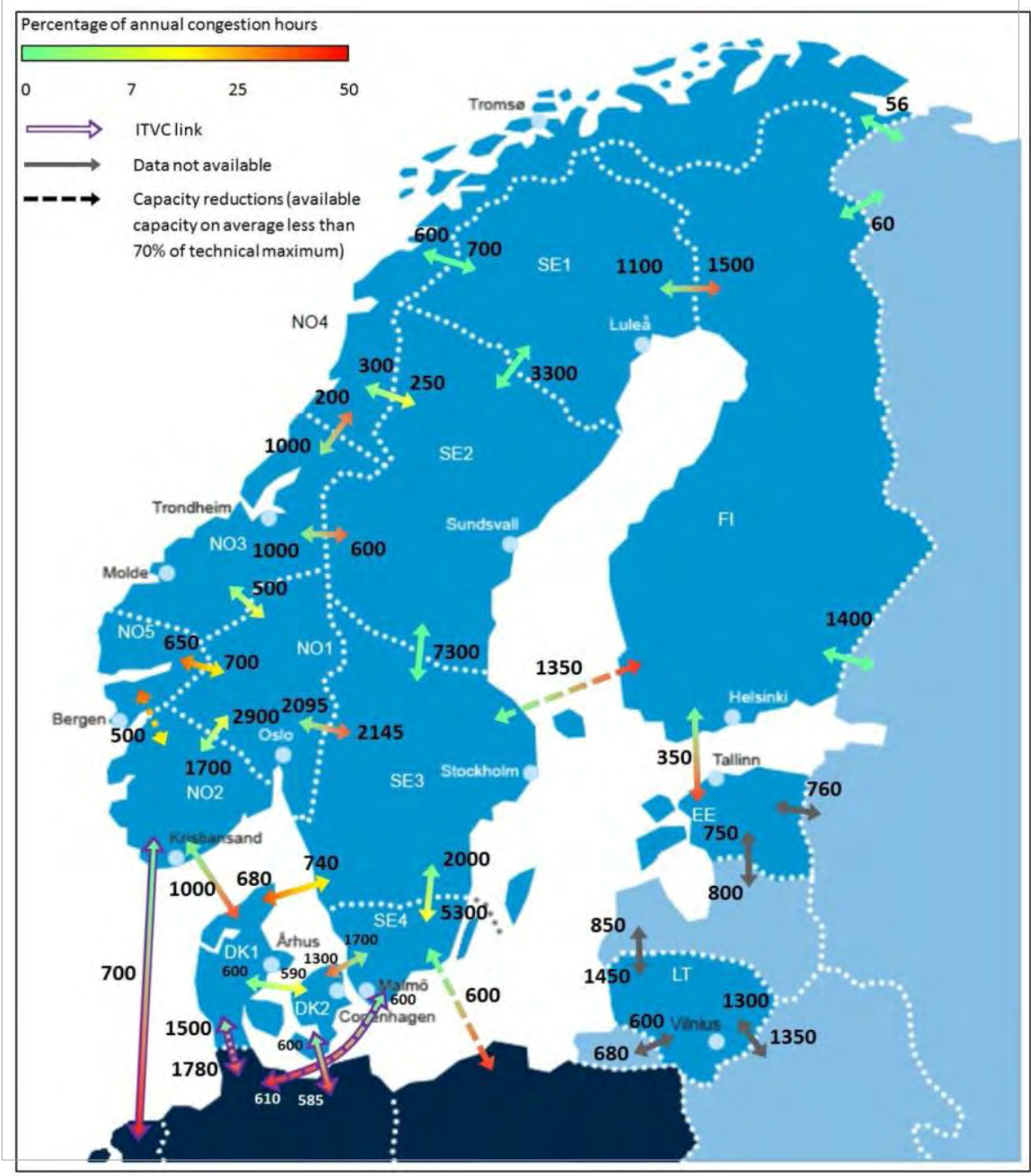

Source: NordReg (2013).

The Nordic TSOs are foreseeing significant grid investment for the next decade, both as upgrades, new grid to connect renewables and interconnections within the Nordics and towards the rest of Europe. Table 7 shows estimated investments in transmission and interconnectors for the four countries the next ten years.

According to the Swedish grid development plan (2013), the Swedish government has the ambition to invest in order to eliminate bottlenecks within the Nordics and towards Continental Europe.

Increased transmission capacity serves to limit price differences across borders; it limits extreme peak prices and enables the sharing of flexibility across the region. More capacity to Continental Europe may increase the value of flexibility in the Nordic region as the markets south of us has more intraday price volatility. 
Table 7: Planned investments in the Nordic transmission grid (incl. interconnectors)

\begin{tabular}{ll} 
Norway & $6,1-8,5$ billion EUR \\
Sweden & $6,1-7,2$ billion EUR (2025) \\
Denmark & 2,7 billion EUR (2021) \\
Finland & 1 billion EUR (2022) \\
\hline
\end{tabular}

Source: Statnett (2013), SVK (2013), Energinet.dk (2013) and Fingrid (2012).

\section{Distribution grid}

Several of the Nordic countries face major investments in the distribution grid. Estimates made by the Norwegian regulator NVE stipulates investments of approx. 9 billion euros in the distribution grid within the next decade. An impact assessment prepared for the Finnish Ministry of Employment and the Economy (2012) estimates similar investments of approx. 3.5 billion euros in Finland. According to Dong Energy in Denmark the implementation of smart technology and better measuring, surveillance and control of the grid revealed that the capacity in the distribution grid was larger than anticipated. The larger capacity implied a reduced need for further grid investments and/or flexibility from the demand side. Large investments in the distribution grid the upcoming years increase the grid capacity, and limit the value of demand reductions during peak load hours.

Smart meters are installed for all consumers in Sweden (daily measuring) and Finland (hourly measuring). Both Norway and Denmark have decided to implement smart meters for all grid customers within 2020, which imply that all Nordic grid customers will have smart meters in few years. Smart meters provide distribution companies with more accurate data on loads and flows. Better surveillance, measurement and control of the grid may reveal more grid capacity (as in Denmark), enable more efficient grid operations and consequently limit the demand for (and value of) flexibility from consumers connected at the DSO level.

\subsection{Developments in market solutions and regulation}

The design of market solutions and regulations affect the amount of flexibility provided in the market, both in the energy markets and to the TSOs in the balancing markets. The developments are along two dimensions:

1. Products and product structure. The way that individual products are defined (ref section 3.3.1 and 3.3.2) determines to what extent generators and consumers are able to bid their flexibility into the market. The combined mix of products determines the overall level of flexibility provided in the market.

2. Market integration. Integration of markets limit the need for flexible resources since larger systems manage uncertainties and variations more efficiently that smaller systems. Integration will allow for 
flexible resources to be more efficiently shared across borders in the various market timeframes. The overall value of flexibility may be reduced due to competition. Access to a larger market may however provide sellers of flexibility with new business opportunities.

\subsubsection{Developments in the day-ahead and intraday markets}

Implicit auctions and market coupling is established as target model in the European day-ahead market. This solution is replacing the explicit auctions as the method for capacity allocation on European borders. Further improvements of the methodology are discussed today. All these developments will contribute to make flexibility more efficiently available in the day-ahead market, and thus also limiting the need for flexibility for balancing during operation:

- Bidding zone delimitation: Bidding zones may in the future to a larger extent be defined by congestions in the power system as opposed to national borders. This will provide more efficient price signals to price sensitive generators and consumers in the day-ahead market and improve the efficiency within the bidding zones and of the crossborder flows/trading.

- Flow-based capacity allocation: Flow-based solutions allocate capacity by optimising total economic surplus within the physical limits of the grid (traditionally capacity has been set by TSOs before the optimisation is done). Flow-based allocation may provide for a more efficient utilization of resources within bidding zones and across borders.

- Close to real-time. Trading intraday (and possibly also day-ahead) may in the future take place closer to the hour of operation. The two physical markets may also at some stage merge. This may serve to limit imbalances and the need for TSO-balancing.

- Time resolution. A shift from hourly resolution to 15-minute resolution is discussed. This will make new flexibility visible in the market place also limiting some of the operational challenges and balancing needs that the TSOs experience today when hours shift.

February $4^{\text {th }} 2014$ market coupling was established in Northwest Europe, known as the Price Coupling of Regions (PCR) and is now including the Nordic region, the Baltic region, Germany, Austria, France, the Netherlands, Belgium, Luxembourg, the UK, Switzerland, Spain, Portugal, Italy and the Czech Republic. Flexibility provided in the day-ahead market is thus traded across this combined region. This market is to be expanded to become a platform for a common European day-ahead market. The Northwest European region is currently working to similarly create a common intraday market, also to be expandable to become a European solution. 
Product development and geographic integration of the day-ahead and intraday markets serves to attract more flexibility into the markets, improving competition, reducing costs of managing fluctuations in demand and limiting the need for TSO balancing real-time.

\subsubsection{Developments in markets for balancing}

TSOs are also working along the same axis of product development and cross border integration. The aim is to both limit the demand for balancing resources and making more balancing resources available at a lower cost.

Statnett has identified three areas driving the demand for balancing resources:

- Deviations between scheduled and actual generation and load.

- Unforeseen incidents.

- Inefficient market design features such as the hourly time-resolution.

We expect future developments that will address all the three areas that will further limit the demand for balancing resources in the future for all Nordic countries.

First, the deviation between schedule and actual generation/load is reduced. Market players are becoming better at predicting generation and load, due to better weather forecasts and opportunities to trade closer to real-time.

Second, significant investments in the grid will improve security margins limiting the risk of unforeseen events in the grid.

Finally, developments in the market design may both serve to limit the demand for balancing resources and to provide for more cost efficient balancing (se chapter 5.4.1). Further, in order to attract more balancing resources at a lower cost the TSOs are likely to develop more tailor made products, also accepting smaller volumes and purchasing more short-term (daily/weekly auctions as opposed to quarterly/yearly).

The Nordic TSOs work to harmonize products across the region and towards adjacent regions (ultimately across Europe) in order to facilitate competition, trade and cooperation. The Nordic market for tertiary reserves (regulerkraft) is to be complemented with a new Nordic market for Load Frequency Control (LFC). There are also bilateral projects and agreements to exchange balancing resources, e.g. are Svenska Kraftnät and Statnett in the process of establishing a pilot project for allocating capacity on the Hasle-cut for exchange of FRR-A and Energinet.dk and Statnett have agreed to allocate capacity on SK4 to exchange LFC. 


\subsubsection{Developments of capacity markets}

Several countries in Europe have implemented various forms of socalled capacity mechanisms, and more are to follow. Capacity mechanisms imply that generators and load receive a fixed payment - usually per annum - in order to be available in the market. Some capacity mechanisms only remunerate generation capacity, but the trend is towards more market based and market wide solutions that also include flexible load. Thus far, however, capacity mechanisms are national in scope and individually designed from country to country. Loads that participate in the mechanism are obliged to limit their off-take from the grid to a certain maximum amount during times of stress in the system. Notification times and the definition of stress varies from system to system.

The impact of capacity mechanism on the demand for and value of flexibility is uncertain, due to two opposing effects:

- Capacity mechanisms tend to increase the total generation capacity in the system, thus reducing the value of flexibility.

- Capacity remuneration for loads incentivize development of demand response in order to participate in capacity mechanisms.

Capacity mechanisms are introduced for security of supply reasons, and are typically linked to a concern that energy-only markets with increasing shares of intermittent and unpredictable renewable generation will not be able to promote sufficient investments in controllable and flexible generation capacity to cover demand in peak load. An important design element in capacity mechanisms is the definition of the capacity adequacy level, i.e. to determine how much capacity the market needs. The capacity adequacy assessment will be based on forecasts of demand and supply, taking uncertainty into account. Since the purpose of capacity mechanisms is precautionary and can be seen as an insurance policy, it is often argued that the capacity adequacy requirement will be set "too high". Moreover, most capacity mechanisms fail to, or only partly, take contributions from cross-border capacity into account. With more flexible generation capacity in the system, capacity shortages will occur less frequently and be less severe. Hence, price variations in the spot and intraday markets will be muted.

On the other hand, demand side participation in capacity mechanisms is encouraged and recommended by the EU guidelines on capacity mechanisms. This means that demand response can compete with flexible generation capacity for capacity remuneration. Generally, this should stimulate increased supply of demand response, particularly for larger loads, such as industry, which may be able to reduce or move peak loads. Smaller consumers, such as households and small industry, would probably not find it profitable to participate in capacity mechanism. Hence, demand response among these consumers is not likely not be enhanced by imple- 
mentation of capacity mechanisms. In the longer term, however, services aggregating demand response among small consumers could develop.

\subsubsection{Market solutions and regulations formalized in European network codes}

The market solutions discussed previously in this chapter are being defined in European regulation. The aim is to facilitate the harmonisation, integration and efficiency of the European electricity market. The main regulatory framework for this harmonization is the so-called 3rd Energy Package (Regulation (EC) No 714/2009), consisting of one Directive and a number of Regulations. The Directive required transposition in national legislation, while regulations are directly binding requirements for all Member States.

Part of the package is to establish Network Codes as a set of direct binding rules. Network Codes are drafted by ENTSO-E, with guidance from the Agency for the Cooperation of Energy Regulators (ACER). Most of the Network Codes are expected to be formally adopted by the end of 2014. The Network Codes are to a varying degree also covering the areas of responsibility for DSOs. The Codes are often referring to the "relevant network operator" being it a DSO or a TSO. The distribution of roles and responsibilities between TSOs and DSOs is being discussed as part of the process of developing Network Codes.

The Network Codes regulate markets, operations and connection:

- Market codes: These codes define the market solutions where flexibility is priced and traded, including Network Codes for Capacity Allocation and Congestion Management (day-ahead and intraday markets), Electricity Balancing (balancing markets) and Forward Capacity Allocation (forward markets).

- Operational codes: These codes define the minimum criteria and the roles of the system operators (DSOs and TSOs) related to ensuring system security and security of supply. There are four operational codes; Load Frequency Control and Reserves, Operational Security, Operational Planning and Scheduling and Emergency and Restoration. When these Network Codes define minimum criteria for system operation in Europe, they also affect the demand for balancing reserves and thus also the value of flexibility.

- Connection codes: These codes regulate the connection of generation and demand to the grid. There are three Connection codes; Requirements for Generators, Demand Connection Code and HVDC Connection Code. These Network Codes define the roles and the relationship between TSOs and generators/consumers/ DSOs and set the minimum criteria for connections. The requirements relate to the size and impact of the units connected to the grid, whereas stricter 
requirements apply to units that have bigger impact on the network and on cross-border power exchange.

The DSO level is both directly and indirectly affected by the Network Codes. The Codes regulate how TSOs are to connect generation, consumption and DSOs to the national grid, but some codes also have direct impact on the DSO by regulating system operations and the connection of new generation and load on the distribution level. The Network Codes defines a minimum level of requirements to all member states. The Nordic region where the power system already is quite efficient will therefore be less affected by regulations in the Network Codes than areas with a less developed market system. 



\section{atd \\ 6. How can demand flexibility be efficient?}

The need for flexibility in the power system can be met by resource on the supply side, storage of power/heat, grid expansions and interactions with other energy systems such as heating and gas, and by demand flexibility. The competitiveness of the demand side in delivering flexibility depends on the cost of demand flexibility and the availability alternative flexibility in the market. Whether the demand response has the characteristics of the flexibility demanded, is an additional question. Descriptions of the potential for consumer flexibility often lack the detailed characteristics of this potential - and thereby cloud the technical potential to deliver flexibility services. Efficient participation of demand flexibility in the Nordic market requires efficient markets in general, including price signals facing the consumer to reflect the market price and underlying cost drivers of electricity distribution.

Analysing the competitiveness of demand response is not within the scope of this project, but in this chapter we will further explore the cost components of demand flexibility and discuss possible measures to promote demand flexibility.

\subsection{Estimated potential for demand flexibility}

\subsubsection{The estimated Nordic potential}

Gaia (2011) estimated the potential for demand flexibility in the Nordic countries (Figure 14). Most of the flexibility is in Sweden and Norway, there is some flexibility in Finland and very limited in Denmark.

The volumes identified are uncertain and there are economical, technical and practical barriers to realising these volumes. Increased energy efficiency may further "threaten" to reduce the potential for demand response by limiting the use of electric hot water tanks in buildings. 
Figure 14 Potential for demand response in the Nordic countries (Gaia 2011)
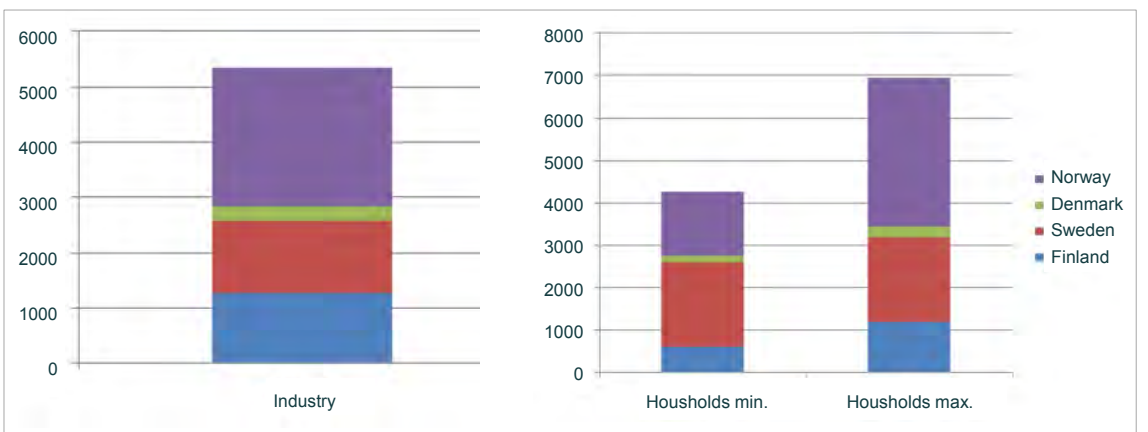

Source:Gaia.(2011)

\subsubsection{Examples of potentials from different consumers}

Several studies have estimated flexibility potentials from different types of loads. Most studies focus on the technical potential, represented by flexibility volumes. The characteristics of the flexibility for different types of loads are usually not addressed and the value of flexibility in different markets is thus to a limited degree understood.

Norwegian households. The Norwegian research group SINTEF Energi and a DSO did a study focused on daily demand response from households in Norway. They used smart meters with hourly metering, remote load control, time of day tariff and a token provided to the customers indicating peak hours. A demand response of $1 \mathrm{kWh} / \mathrm{h}(1 \mathrm{~kW})$ for customers with electrical water heaters was observed. By aggregating this response, the potential for demand response from 50 per cent of Norwegian households is estimated to $1000 \mathrm{MWh} / \mathrm{h}$ (corresponding to 4.2 per cent of registered peak load demand in Norway).

Swedish heaters. The Elforsk project "Effektstyrning på användarsidan vid effektbristsituationer" (2006a) examined the possibility to control the load of the electric heating and water heaters owned by Swedish customers with home automation. The experiment showed an average controllable load of 4-5 kW per house at 10-15 degrees below zero. The results imply a technical potential for load control of electric heating for up to two hours of a total of $1500 \mathrm{MW}$ in Sweden.

Swedish medium-sized industry. Elforsk (2006b) analyses the conditions for load reductions measures by medium-sized electricity customers (ironworks and steelworks, foundries, the chemical industry, the food industry, the heat treatment industry and the real estate industry). The study estimates the total potential for these customers to lie between 300 and $340 \mathrm{MW}$. The real estate industry contributes with more than $200 \mathrm{MW}$ of the potential. The large potential in this industry is caused by the low costs of the load reduction and that it is relatively easy to postpone the start-up of ventilation systems with up to three hours. The industrial companies may contribute with load reductions up to 130 MW. The potential depends on the state of the market as large parts of 
the load reductions have to take advantage of over-capacity utilization. The duration og load reduction from the industry is one to two hours.

Swedish PII. The Swedish power system was at the beginning of 2000 characterized by having a tight capacity balance. In that regard Svenska Kraftnät and Energimyndigheten established the project "Industribud" with the purpose to trigger load reductions in the industrial sector on market based conditions. The project included about 30 power intensive industries, of which most of the companies had the possibility to reduce their load with 5-50 MW a few hours. The total technical potential for load reductions in the power intensive sector was estimated to 1600 MW. To achieve the full potential requires very high prices (up to 13000 SEK/MWh) (SVK, 2002).

Danish service sector. EA Energianalyse (2011) estimates that about 5 TWh of the Danish electricity use in the industry, trading and service sector may shift their electricity consumption up to 12 hours. However, the industry requires very high prices to alter their consumption patterns. A majority of this flexibility is defined as load-shift flexibility. According to EA Energianalyse 50 percent of the electricity used for cooling and freezing processes in production companies might be flexible, while as much as 70 percent of the electricity used for the same purposes in the trade and service sector might be flexible (supermarkets). Supermarkets are closed during nights and may use these hours for extra cooling, which may reduce their demand for cooling during peak hours in the morning. Ventilation is the second largest contributor to demand flexibility at large electricity consumers. EA Energianalyse (2011) estimates that 15 percent of the electricity used for ventilation in the trade and service sector might be flexible. Electricity used for ventilation in industrial companies is expected to have a larger potential for flexibility due to a less sensitive comfort level in this sector.

\subsection{The costs side of flexibility}

Relevant costs for enabling demand response from industry, large buildings and households are:

- Cost of consequences of demand response.

- Time and management cost.

- Costs of handling external data.

- Costs of technology and service providers.

The consumers have a decision making process where they consider the costs listed above against potential revenues from selling flexibility in the market. Figure 15 illustrates this decision making process. 
FIGURE 15

Figure 15: Decision making process for a provider of demand response

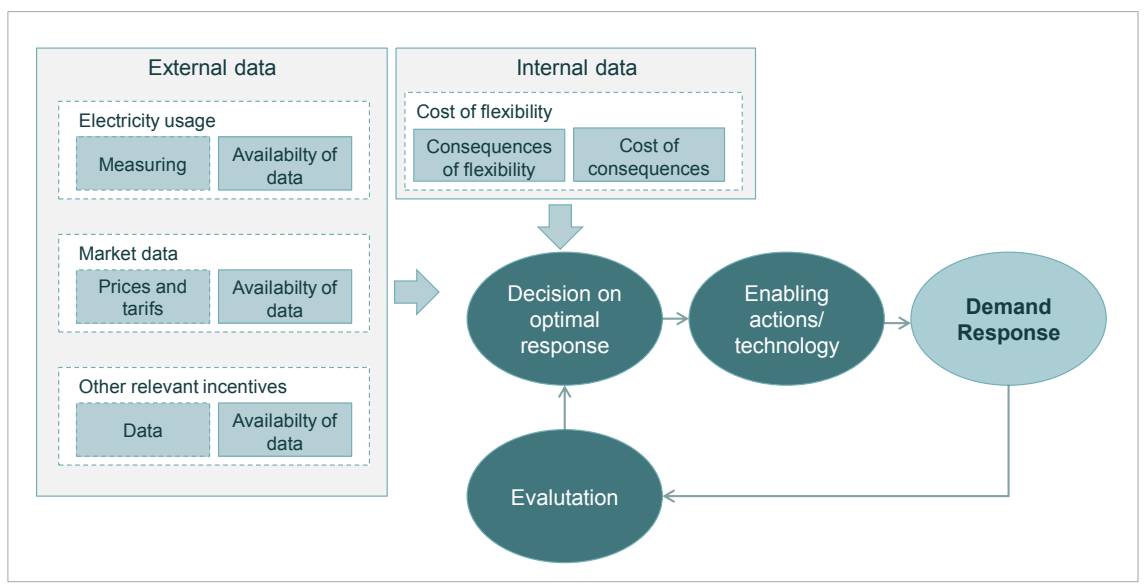

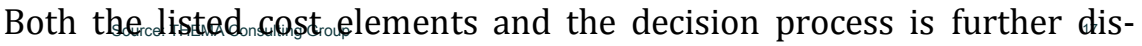
cussed in this chapter.

\subsubsection{The cost of consequences of demand response}

The consumers cost of demand response will vary significantly depending on the actual consequence of changes in electric loads. The costs of shutting down electricity usage or to shift the consumption to a different time has a cost to the consumer in terms of lost production of goods/ services or reduced comfort level. Hence the limited price sensitivity of electricity consumption. The cost of lost services or production depends on how consumers value these services and products.

Costs and consequences are summed up in Table 8.

Table 8: Costs of consequences of demand response

\begin{tabular}{llll} 
Type of flexibility & Type of load & Cost for industry & Cost in buildings \\
$\begin{array}{l}\text { Shut down energy } \\
\text { usage }\end{array}$ & $\begin{array}{l}\text { Processes that may be } \\
\text { interrupted }\end{array}$ & $\begin{array}{l}\text { Value of goods not being } \\
\text { produced and possible } \\
\text { fees or loss of goodwill } \\
\text { for not delivering }\end{array}$ & $\begin{array}{l}\text { Reduced comfort and } \\
\text { loss of productivity }\end{array}$ \\
$\begin{array}{l}\text { Shift in type of energy } \\
\text { source }\end{array}$ & $\begin{array}{l}\text { Loads supported by back- } \\
\text { up with alternative } \\
\text { energy source }\end{array}$ & $\begin{array}{l}\text { Fixed cost of having an alternative fuel source (capital } \\
\text { costs, maintenance and operation). }\end{array}$ \\
$\begin{array}{l}\text { Shift in time of elec- } \\
\text { tricity usage }\end{array}$ & $\begin{array}{l}\text { Loads with inertia } \\
\text { Lust }\end{array}$ & $\begin{array}{l}\text { No cost if production and } \\
\text { quality are not reduced. }\end{array}$ & $\begin{array}{l}\text { No cost if comfort and } \\
\text { productivity is not } \\
\text { affected. }\end{array}$ \\
& $\begin{array}{l}\text { Loads or processes with } \\
\text { storage or cache }\end{array}$ & $\begin{array}{l}\text { Cost of keeping cache in } \\
\text { the production process. }\end{array}$ & $\begin{array}{l}\text { Cost of installing } \\
\text { storage and loss of } \\
\text { stored energy. }\end{array}$ \\
& $\begin{array}{l}\text { Processes or appliances } \\
\text { with excess capacity }\end{array}$ & No loss if limits are not \\
broken & $\begin{array}{l}\text { The cost of planning } \\
\text { and adjusting }\end{array}$ \\
\hline
\end{tabular}

The loss from replacing the use of electricity with another energy source is simply the price difference between the alternative fuels, and the cost 
of providing for the backup energy source, since industrial output and comfort level is unaffected.

If the time and frequency of interruption is limited according to the actual inertia or cache/ storage, these loads may be interrupted without any practical or noticeable consequences.

If there is a risk, even a small one, that interruption in electricity consumption may affect the total production or comfort, this risk itself may have a significant cost even if the interruption does not happen since consumers will have costs related to preparing for an outage.

\subsubsection{Time and management costs}

All changes in how and when energy is spent, both in the industry, service industry and buildings, require management attention and costs related to manning, analysis and preparatory work. These costs are often underestimated when evaluating potentials for energy efficiency and demand responses. Nevertheless, this cost may represent an important barrier to realise the potential for demand flexibility, and could limit the availability of otherwise economic viable flexibility.

The smaller the loads in question, the more critical is the impact of cost of time and management on whether to unleash the economic potential of demand response. Small loads (buildings) must be handled in a simple and standard way to reduce costs - or they will not be cost efficient compared to larger loads (industry) or generation.

\subsubsection{Costs of external data}

Demand response is triggered by price signals in the market and access to external market data is a prerequisite for demand response. The following four requirements apply to the availability of external data:

1. On the right timeframe. The timeframe for input data (e.g. price signals, consumption limits related grid tariffs or signals from system operator) and output data (measured consumption) must correspond to the time frame of demand response.

2. For the relevant players. Demand response may be activated by the consumer or by third parties (e.g. suppliers, providers of energy services, aggregators or a system operator). Activation may be done manually or automatic.

3. On a standardized and user-friendly format. Cost efficient automatic IT-solutions is in most cases critically important, in particular is this the case for small loads.

4. In a safe and cost efficient way. Internet may be used for collecting general data like spot prices and grid tariffs to be used by home automation. However, it may not be either safe or efficient enough for 
service providers to send direct response signals to change loads in buildings through internet. For such purposes, the communication channel set up to collect measure data from smart meters will be a better alternative (THEMA and Devoteam daVinci, 2012).

\subsubsection{Cost of services and technology enabling demand response}

Service providers may bring additional volumes of flexibility to the market when they improve margins though economies of scale (limiting costs) and better optimization of flexibility (enhancing revenues). The cost of service providers are shared among the customers and will normally include:

- Technology. Investment and implementation of equipment for exchange of information, optimization and execution of load changes (included in-house communication). Energy management systems and automation are relevant both to improve energy efficiency and to enable demand response.

- Competence. Competence on e.g. power markets, market operation, trading, risk management, regulatory issues and new technology.

- Administration. Costs of performing the services provided to the customer.

Table 9 lists some products offered in the Nordic market and their prices.

\begin{tabular}{|c|c|c|c|c|}
\hline Country & Service provider & Product & Instalment cost & Fixed monthly cost \\
\hline Finland & Helsingin Energia & $\begin{array}{l}\text { Termo home } \\
\text { automatation }\end{array}$ & 600 Euros & 6 Euros \\
\hline Finland & Fortum & Fortum Fiksu & 124 Euros & $\begin{array}{l}15 \text { Euros (first three years) } \\
4,95 \text { Euros (succeeding years) }\end{array}$ \\
\hline Norway & Lyse Energi & $\begin{array}{l}\text { Smartly heating } \\
\text { control }\end{array}$ & 850 Euros* & 4,75 Euros \\
\hline Norway & Lyse Energi & Smartly light control & 1000 Euros* & 3,50 \\
\hline Sweden & Ngenic & Ngenic tune & $\begin{array}{l}550 \text { Euros } \\
333 \text { Euros }\end{array}$ & $\begin{array}{l}0 \\
5,50 \text { Euros }\end{array}$ \\
\hline
\end{tabular}

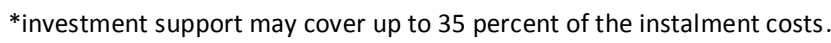




\subsection{Are the consumers faced with efficient price signals?}

A prerequisite for demand response is that consumers are faced with efficient price signals. As described earlier, the consumer experience price signals in the day-ahead and intraday markets, in grid tariffs and in balancing markets. Measurement data and market data must also be available to the consumer and/ or service providers in the right time frame and the right format for the consumer to be able to respond to price signals.

\subsubsection{The total cost of electricity differs between countries and the size of consumers}

The Nordic electricity bill consists of the following components: power price, grid connection/usage cost (grid tariff) and tax. Taxes and levies that are not linked to tariffs or power price serves to limit the strength of the price signal. Figure 16 below illustrates the composition of the electricity bill for households and large industry in the Nordic countries.

Figure 16: The total price of electricity for Nordic consumers

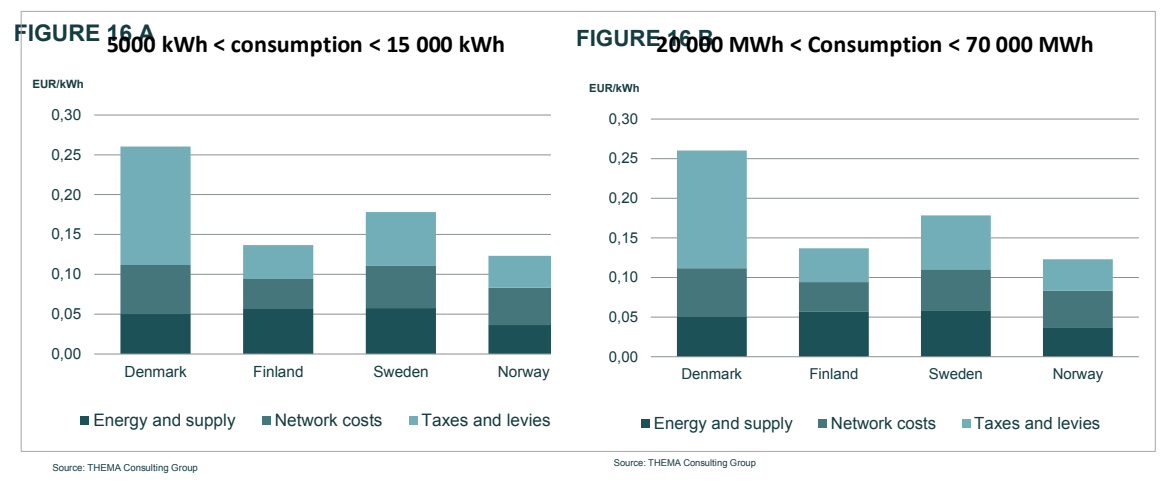

Source: Eurostat (2014).

As reflected in Figure 17, there are large price differences between the two groups of customers. Network costs cause most of the difference. Prices are relatively equal in the Nordics for small for large industry while prices for households vary significantly, mainly due to different levels of taxes and levies.

\subsubsection{Price signals in the spot prices}

The Nordic electricity suppliers offer a variety of supply contract. Fixed price contracts, spot price contracts and default suppliers contracts are the most common types of contracts used in the Nordic market: 
- Fixed price contracts, for example for one year, imply that the power supplier cannot alter the price during the contract period, even if the spot prices change.

- Variable price contracts implies that the electricity price changes based on changes in the spot price level, but hourly price variations is not reflected.

- Spot price contracts charge the customers the Elspot price plus a fixed mark-up.

- Customers who do not actively choose a power contract are on socalled default suppliers contracts. There are two default suppliers' contracts; one provides an assurance that consumer has access to a retailer with price protection ${ }^{2}$ for consumers. The second only provides an assurance that the consumer can purchase electricity from a predetermined supplier (NordReg, 2013b).

Contract type affects the customers' incentives to be flexible. The price signals to the consumer will only be influenced by the spot price if the hourly price is reflected in the contract between the supplier and the consumer. In that regard, both spot contracts and hourly prices are preconditions for the customers having incentives to shift consumption between hours. Fixed price and variable contract offer no incentives for the customers to shift demand between hours. Variable contracts may provide an incentive to respond to more long-term price differences. If the power balance lifts power prices up on a permanent basis, this will be reflected in the price in a variable contract, providing an incentive for consumers to consume less. Fixed price contracts "hide" most of the price signal, which imply that the customers have close to zero incentives to react to the underlying spot price.

Figure 17 illustrates the price differences in the retail market between the four countries. Norway and Sweden, where a substantial part of the consumers are on spot contracts, have the retail prices varying throughout the year while consumers in Finland and Denmark where large parts of consumers are on default suppliers contracts, (NordReg, 2013b) experience more flat prices throughout the year.

\footnotetext{
2 Denmark has opted for the first model. For this supply product the Danish Energy Regulator Authority (DERA) regulates the price to ensure that the mark-up on these products is not higher than the mark-up on corresponding products in the free market. In Finland the prices for the customers under obligation to supply contract are not regulated as such, but the prices have to be reasonable.
} 
Figure 17: Retail prices in the Nordic countries in 2012 (excluded VAT, taxes and grid|t女FiffSE 17

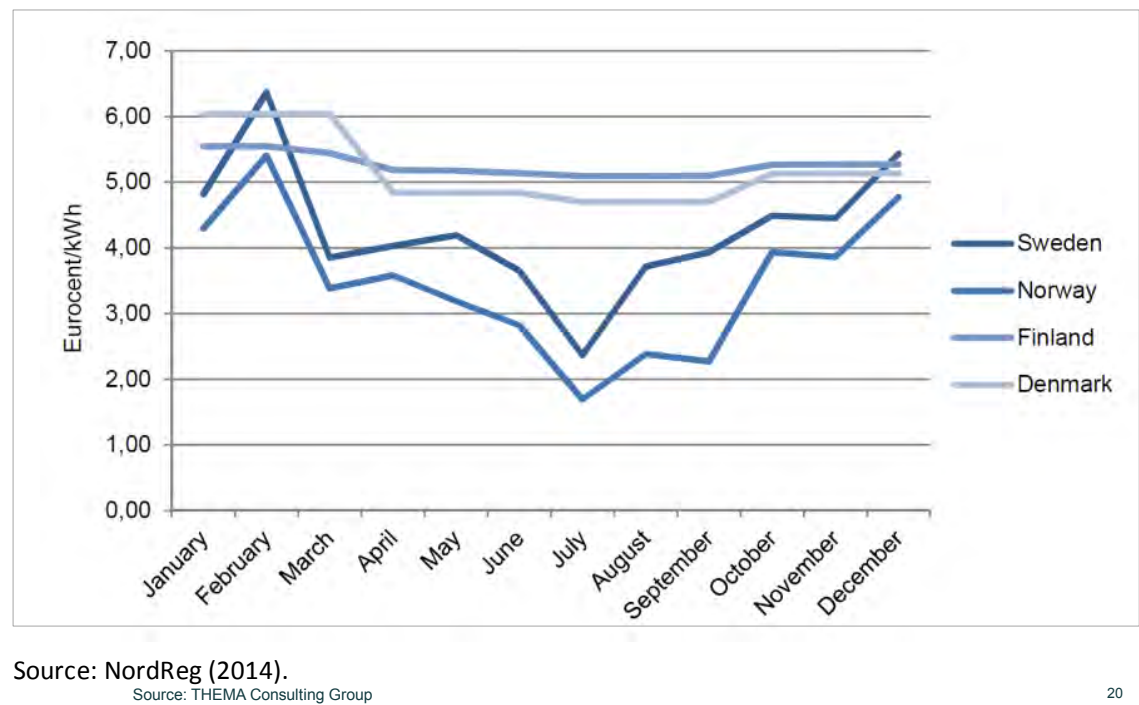

\subsubsection{Cost of imbalances}

As described earlier, BRPs are faced with the cost of the imbalances they cause. The spot price is set to balance bids (supply) and offers (demand) in the day-ahead market. Flexibility of consumers is reflected in price sensitive bids. However, demand response may also imply that consumers adjust their load intraday and after the spot price is set, potentially limiting load to levels below what was anticipated day-ahead. The possibility to limit consumption intraday may lead to imbalances for the power supplier being a Balance Responsible Party (BRP). Only large consumers participating in the day-ahead market have balance responsibility. The retail companies nominate volumes in the day-ahead market and have balancing responsibility on behalf of their customers being households, large buildings and SMEs. Thus, large consumers and retail companies may want to balance their portfolio in the intra-day market in order to limit imbalances.

The retail companies bundle the cost of balancing into the margin they charge their customers. Thus, small consumers are not individually exposed to the cost of imbalances. The cost is implicit in the retail electricity price and there is no price incentive to the individual consumer. As a consequence, if there is a large total volume of demand response from non-BRP based on the day-ahead price, this may in theory have effect on the intra-day price, and thereby creating a situation of overreactions in the intra-day price for the hours with high day-ahead prices. Such development may create unpredictability in the hourly prices and reduce the markets understanding and reliability in the price formation. This effect is described in SWECO (2011) and Elforsk (2013). We do however expect this intraday flexibility to develop somewhat over time and that the BRP will be able to observe, learn and adjust their bidding 
strategies in the day-ahead market accordingly. Thus, we see the negative consequences for price formation in the intra-day market described by SWECO and Elforsk in reality to be limited (see however chapter 5.4.5 for a discussion of the cost of imbalances for the retailer caused by demand response).

\subsection{Possible measures to more efficiently use demand flexibility}

As a general rule in economic efficient markets, measures should only be implemented to correct market failures having a negative impact on the efficiency in the market. There are three main types of measures:

- Economic: This includes subsidies, taxes and levies.

- Regulatory: Regulation of markets and the energy sector in general, but also general imposes and standard.

- Information: This includes information campaigns and education.

The more efficient the overall regulation of the Nordic power market is, the more likely it is that demand flexibility will be utilised in an efficient way. Therefore, some measures that are considered to increase efficiency will promote demand flexibility which is cost-efficient, but in some way is hindered to take part of different markets. Measures that more specifically affect demand flexibility should be limited to remove obstacles for the demand side to take part in the markets where flexibility has a value.

\subsubsection{Measures for efficient pricing of flexibility}

Efficient pricing of demand flexibility entails the following:

-Value: The true willingness to pay for flexibility is visible in the market.

- Cost: The true cost of demand flexibility is visible in the market.

- Competition: Demand flexibility is exposed to competition from other flexibility providers (power generation, storages and alternatives in heat and gas).

Thus, demand flexibility is in particular attractive when the value of flexibility is high and the cost of demand flexibility is low compared to the cost of alternative sources of flexibility. We also observe that efficient use of demand flexibility requires efficient markets in general. Thus, we do not specifically consider market solutions tailored to promote demand response. Demand response has to compete with flexibility provided by others. 
In the following we discuss measures that promote efficient pricing of flexibility in three market timeframes. These measures are not necessarily designed to promote flexibility in demand - some measures may limit the overall need for flexibility while other measures may create opportunities to import flexibility from adjacent areas. Thus, the overall aim is efficiency, and demand response can contribute to the extent it is more efficient than alternative providers.

1. Energy trading (the planning phase):

a) Market solutions that efficiently reflects the physics of the power system, making consumers exposed to the real cost of power consumed and generators and grid compensated for the value of what they deliver. Some specific measures (described in 4.5.1) include more efficient bidding zone delimitation, flowbased market coupling and market gate closure closer to realtime and thereby significantly limit the demand for balancing resources, as indicated in Figure 13.

b) Standardized products promoting liquidity, efficient competition and an ability to "show" flexibility in the market. Three specific measures includes to integrate markets by adding more member states and regions to the NWE market coupling, be open to add variants promoting flexibility such as block-bids and flexible one-hour bids and to consider having a shorter time-resolution (e.g. replacing one hour with 15 minutes).

2. Real-time balancing (the operational phase):

a) Standardize target models and integrate markets across borders and regions to provide market players with access to larger markets and more efficient competition.

b) Consider developing a product that allows for more flexibility on key elements of products in the market, such as accepting smaller bids, various durations, various recovery times and various response times. In this context, products could to some degree be tailored to attract demand response, but demand will still have to compete with other providers of flexibility. The providers bid their flexibility into the market and compete on both volume and price. The TSOs could provide transparency on what resources they purchase and on their estimates for future demand for flexibility. This could serve to develop a market for short-term flexibility where demand could compete with other providers in the market.

3. Forward reservation/capacity markets. In addition to the short-term prices for flexible resources in the spot/intraday and balancing phase, forward reservation/capacity markets may be considered in order to ensure capacity adequacy: 
a) Reservation for energy trading. In the market for energy trading, consumers buy electricity from generators. Long-term reservation entails that TSOs intervene in the market to ensure security of supply, including to reserve flexibility, in defined future periods by providing an additional payment to selected market participants who are obliged to bid flexible capacity into the energy markets (defined energy volumes). Including demand in such mechanisms would promote demand side flexibility from large loads. Large industry already contribute in the Norwegian Energy options and as strategic reserves in Sweden. To the extent that capacity mechanisms unduly increase generation capacity, however, they reduce the value of demand side flexibility.

b) Reservation for real-time balancing. TSOs are the sole buyer in these markets, and they are hence not intervening in a market place in the same way as with reservation for energy trading. The payment is in this case also providing an additional incentive for making flexible resources available.

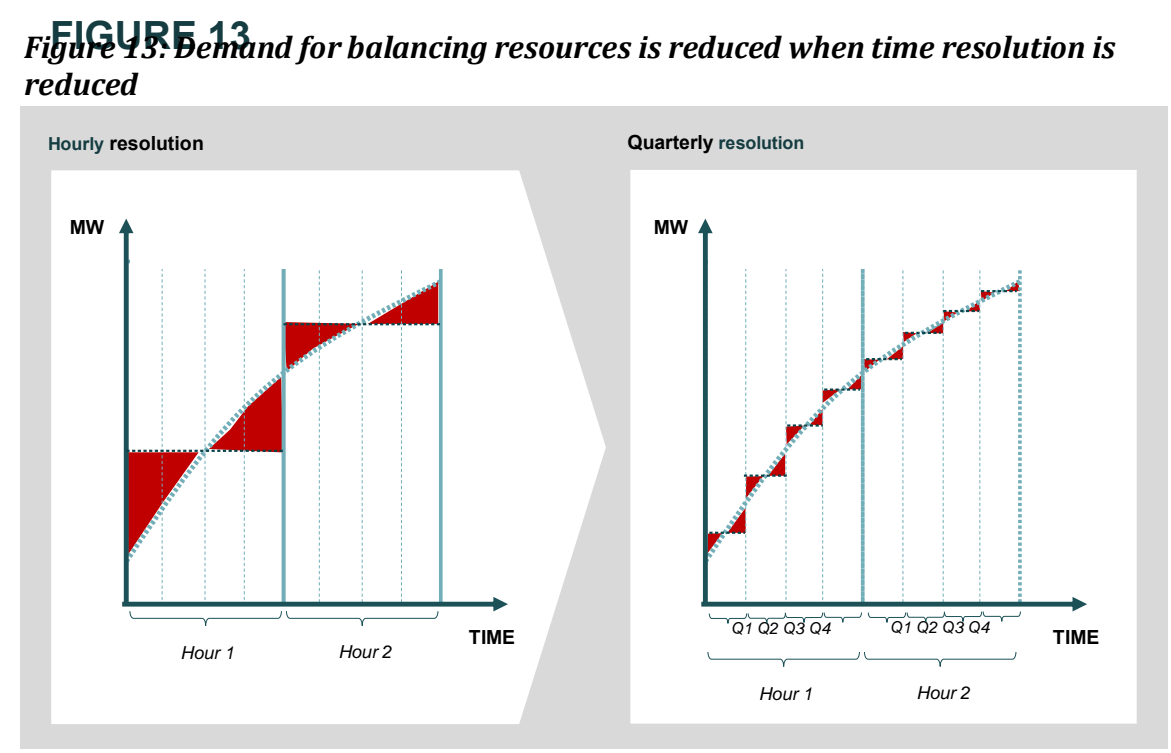

Capacity markets should meet defined criteria (target model), be standardized and integrated across borders and regions to provide markẻt players with access to larger markets and to ensure efficient competition. The various market timeframes should also be considered as a whole, as they are all linked to each other. An efficient energy market may limit imbalances and thus also the need for real-time balancing. Efficient markets for energy trading and real-time balancing may also improve price formation and limit the need for capacity markets. Maintaining an efficient energy market is thus of fundamental importance as 
it both promotes short-term balance and limits the need for market intervention in the form of capacity mechanism.

The ideal solution is that all flexibility is visible in efficient energy markets, limiting the need for TSO balancing in real-time. Figure 18 illustrates an optimal development, combining the measures to make markets more efficient and integrate them across borders and regions. First, national market solutions are replaced by Nordic market solutions (also interregional and European) promoting competition and access to larger markets for the providers of flexibility. Second, an efficient market for energy trading reduces the need for forward reservation and for realtime balancing. Such a development will increase liquidity and competition in markets for energy trading contributing to an overall efficiency in the use of resources employed in the power system, including the use of demand flexibility.

Figure 18: Combining measures, creating cross-national markets, directing volumes towards the energy market (spot) and improving the efficiency of the enET(9UARER8

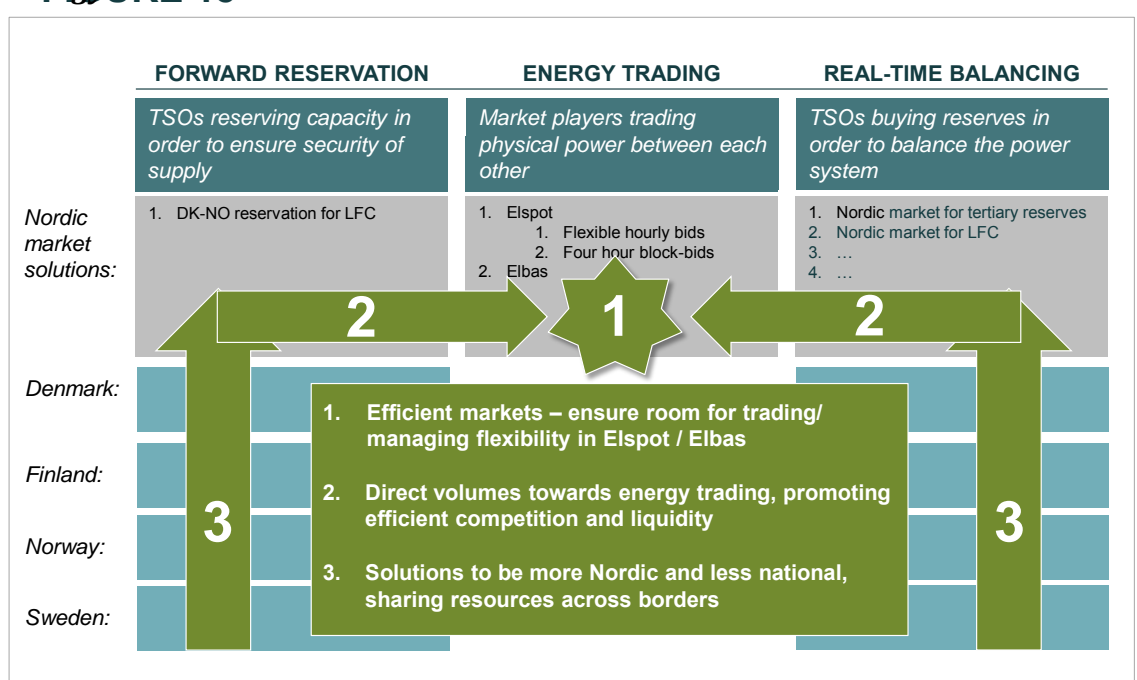

\subsection{2 $2^{\text {Sourec }}$ Reganulation of the grid tariff}

Grid tariffs are part of the price signal to end-users. The structure of current grid tariff models applied in the Nordic markets is outlined in section 3.3.3. The question is whether current tariff models stimulate or mitigate demand flexibility, how tariffs should be designed and to what extent a new design would stimulate demand flexibility in an efficient manner.

In general, efficient prices reflect the underlying costs of consumption of the good. Hence, grid tariffs should reflect the cost of transporting electric power, i.e. transmission and distribution. Above, we have seen that end-users in the Nordic markets to varying degrees are exposed to prices that reflect variations in marginal grid costs. 
The cost structure in the electricity grid is characterized by high investment costs and decreasing unit costs. Doubling of the capacity of the grid implies less than a doubling of the cost. Moreover, the grid is not developed by increments, but in "leaps", both for technical and economic reasons. In addition, the grid has public good characteristics: When the capacity is sufficient, increased consumption by one user does not (or only to a small degree) increase the cost of other users, and if the capacity is not sufficient, all consumers are affected.

Capacity outages are costly to society and electricity supply is considered a critical infrastructure for safety, welfare and health in modern society. Thus, the grid should be able to supply electricity in (almost) all foreseeable situations. The implication is that the grid is dimensioned in order to be able to supply electricity to all customers in peak load situations and even if (any) one grid component trips (so called n-1 principle). ${ }^{3}$ The implication is that in most situations, there is spare capacity in the grids.

In grid operations, the only cost that varies with load is losses. The cost of losses is the percentage of losses per kWh multiplied with the energy price. The percentage of energy losses increase when the grid is operated closer to its capacity, which usually coincides with periods with high load and correspondingly high wholesale electricity prices. Moreover, losses vary between different nodes, according to the balance between supply and demand in each node.

Grid tariffs that vary with energy losses in the grid provide a stronger price signal to consumers than fixed energy tariffs (flat charge per $\mathrm{kWh}$ ). In order to incentivize flexibility in consumption, prices should vary with time of use, reflecting the variation in grid costs at different times, and with location. Energy tariffs that do vary with losses typically strengthen the price signals from the wholesale market as grid costs increase when load is high, as do wholesale electricity prices. Average energy tariffs hence mutes the price signals from the wholesale market, thus reducing the value of end-user flexibility.

Some grid customers are interruptible connections in exchange for a lower tariff. These customers usually have an alternative energy source. Having the opportunity to cut supply to some end-users may contribute to achieving the $\mathrm{n}-1$ criterion, and postpone grid investments. Supplies to interruptible customers are cut when it is necessary in order to balance the grid. The opportunity for customers to become interruptible may however provide incentives for increased flexibility, which make end-users better equipped to respond to peak prices.

Some argue that introduction of capacity pricing would reduce investment costs in the grid and increase end-user flexibility. Capacity

3 The $n-1$ criteria is a common criterion in grid planning. In some areas, as around bid cities, the grid is planned with n-2 or even n-3 capacity. 
tariffs may be designed in different ways, but are difficult to set in a precise way and without adversely affecting the utilization of the grid. General capacity pricing may reduce the utilization of the grid even when capacity is not scarce.

In cases where it is clear that the combined willingness to pay for capacity expansion among the relevant end-users does not exceed the total costs, critical peak pricing may be a relevant option. Critical peak pricing implies that capacity tariffs applies only in critical peak hours, and should incentivize grid customers to reduce load in such hours.

Variable tariffs are not sufficient to cover grid costs. In order to cover total costs, grid customers pay various fixed grid charges. These may be differentiated by type of customer, by consumption or by load. Generally, however, residual tariffs should be neutral and not affect consumer behaviour. Tariffs affecting consumer behaviour beyond the effect of optimal energy tariffs and well-designed critical peak pricing, represent a welfare loss and should be avoided.

To conclude, Energy tariffs according to marginal losses, interruptible contracts and capacity pricing may incentivize increased end-user flexibility. Such grid tariffs should however not be implemented with the purpose of increasing demand flexibility, but only to the extent that they reflect underlying grid costs.

\subsubsection{Regulation of the DSOs}

The overall economic regulation of the DSOs are relevant in discussing efficient utilisation of demand flexibility as an alternative to grid investments to handle peak loads. The economic regulation of DSOs in the Nordic countries is generally based on revenue caps. The strength of incentives in the regulation varies between the Nordic countries, but in general, DSOs have clear incentives to invest and operate in the most cost effective manner, including stimulating demand flexibility when this is the most cost efficient solution. How to determine when demand response and peak shaving is a better solution than increased grid capacity is however a bit more complicated than simple cost calculations and must be regarded in a broader perspective.

The DSO must also take security of supply and power quality into account when evaluating how grid constraints can be handled in a cost efficient way. For demand response to be an alternative to grid investments, the DSO must secure that the demand response is predictable and that the response pattern will remain stable for a sufficiently long time. There have been examples of consumers in Norway that have chosen interruptible connections in exchange for a lower tariff in periods when disconnections have been rare. However, when the frequency of disconnections increases, consumers switch to a grid tariffs with guaranteed connection. Grid investments may take years to plan and build, 
therefore peak shaving must be secured over longer periods of time to be a safe alternative to investments.

It is possible to design economic regulation mechanisms for DSOs that provide stronger incentives to develop (or at least evaluate) consumer flexibility as an alternative to grid investments. However, the lessons learned from both theory and practice shows that it is difficult to design economic regulatory mechanisms that reward utility companies explicitly to reduce grid investments (by choosing other solution than increased grid capacity and / or underinvestment in grid) without negative economic consequences. This is partly due to the complexities we have pointed out above, and partly because the value of demand flexibility and other options will vary depending on the actual situation and is therefore difficult to include in the overall economic regulatory mechanisms.

The Nordic governments may consider strengthening the incentives for efficiency in the grid regulations, but this should not be done without evaluating the effects on security of supply and the power quality, what incentives it will give for the grid companies to invest and taking into account the economics of scale in grid investments.

\subsubsection{Design of supply contracts}

Different energy contracts will give different incentives for demand flexibility. The first aim for governments should be to make sure regulations do not hinder the retailer's possibility to develop and offer electricity contracts that promote demand response, and to remove any obstacles for the consumer to choose such contracts. The roll-out of smart meters also to small consumers is one step in this direction (most large consumer in the Nordic has had smart meters for quite a time already).

There is ongoing work to develop a common Nordic end-user market for electricity. Such development will reduce the barriers for electricity retailers to enter more than one Nordic market. In the common Nordic market it has been suggested a supplier centric model which means that the retailer will be the customers main contact point for both the retailer and the grid company. Grid tariffs and electricity will also be invoiced together.

If, how and when the governments should interfere in which contracts retailer are allowed to offer is discussed in the following. Measures focusing directly on contracts may include:

- Information: public information campaigns to increase the consumers understanding of which contracts that are necessary to get economic benefits from the customers demand response. 
- Regulation of information about the contracts: Provide services that compare different contracts and offers from suppliers and regulate which information the supplier must give the consumer about the contract.

- Regulation of contract types: standardise supplier contracts that may provide demand response or limit the number/ types of contracts suppliers may offer to their customers.

The energy market is complex and may be confusing to the end-users. Due to Ofgem (2011) and Waddam \& Wilson (2007) the small consumers have limits to their ability to take rational decisions in the electricity market. For some users it is difficult to understand how the choice of contracts for electricity supply will impact their cost of electricity. There may also be different types of physiological barriers to change contracts of electricity and such barriers are strengthened by the complexity of the electricity market (THEMA, 2013c).

Hence, there is an asymmetry of information between the customers and the suppliers of electricity. Contracts for demand response may increase the complexity for the end user. This complexity may be exploited by the suppliers by offering contracts that are more beneficial for them than it is for the customer. Standardisation of contracts and regulation of what information the supplier must provide to the consumer may reduce the asymmetry between suppliers and their customers. At the same time, a strict regulation of contracts and contract types may reduce the innovation in this part of the sector and also the customer's freedom of choice. Innovation in the end-user market may be very important as there are big changes happening in the electricity sector. Unless there are indications of severe exploitation of end-users in the electricity sector based on asymmetry of information between the suppliers and their end-users, this is not the right time to impose a strict regulation on products. Providing general information to the customers, on the other hand, will help the customers taking good choices of contracts.

\subsubsection{Demand response and the risk of the retailer}

Demand response could be initiated by a stand-alone service/ technology provider, an aggregator or as an integrated role of the electricity supplier. Two aspects are important when discussing the role of the commercial player initiating the demand response from electricity consumers - which market they may participate in and if they have balance responsibility or not.

Service providers or aggregators that are not BRPs will not have to face costs of imbalances demand response may cause. Whether this is a problem or not, depends on the volumes of demand response and how predictable the demand response is. If the retailer/ BRP can predict new 
responses from the customer or a portfolio of customers, based on previous responses, they will take this response patterns into account when placing volume bids in the day-ahead market. For the response to be predictable, the response must be based on day-ahead hourly prices alone, grid tariffs alone or in combination with other (more or less) predictable data, like weather forecasts. This type of demand response from customers in a portfolio will be reflected in the price formation, but in an indirect way. How well this price sensitivity is reflected in the price formation will depend on the retailers / balancing responsible ability to "learn" from previous responses.

For larger volumes responding to markets or price signals that are not known to the balancing responsible, it will be impossible to predict future demand responses based on previous responses. This will be the case for demand responses based on system services or loads being shut down by grid companies due error states or limiting capacity in the local grid, which may occur unrelated to any data or information the retailer/ balancing responsible may have. If large loads are shifted in time or shut down in ways that are unpredictable, the retailer will face imbalances and the cost related to them, while the economic benefits will end up at a different company. The benefiting companies may be the grid company, the system operator, the aggregator or service provider and/or the consumer itself.

If an aggregator that handles a large portfolio of loads is not a BRP, costs of imbalances caused by the aggregator must be covered by the customers BRP - or by the system as a whole. To avoid the aggregator causing costs that must be covered by others there are two options: the aggregator must serves as a BRP for the volumes they handle or the aggregator/ consumer must have the duty to inform the BRP/ retailer about the agreed terms of load changes between the consumer and the aggregator. In the first option, the aggregator need to take balancing costs into consideration when deciding on load changes. In the second option, the BRP may include costs or risk of imbalances in the contractual terms with the consumer.

Nevertheless, the retailer/ BRP will have stronger incentives to provide their customers with services and technology to exploit demand flexibility than other service providers. The reason for this is that it will give retailers a clear knowledge of the consumers' price sensitivity and to place more correct price sensitive volume bids in the day-ahead market and to reduce their own costs of imbalances. If the retailers also act as service providers for demand response, it gives the retailers the possibility to face the customers with the price incentives in the intra-day market, since only BRPs may trade in this market. Hence, if the retailers provide services for demand response from their customers, the total value of demand response may increase and thereby the incentives to the customers. 


\subsubsection{Taxes and levies}

Taxes and levies may enhance or mute price signals. The main taxes on electricity usages are VAT and electricity levies. Both VAT and levies are substantially lower for the industry than for small electricity users. The electricity levy represents a large share of the total cost of electricity in to small consumers particularly in Denmark and Sweden.

The VAT is a percentage of the electricity price. Thus, VAT enhances price signals from both grid tariffs and electricity prices and strengthens incentives for demand response. Levies, on the other hand, are fixed fees per kWh of electricity used and thereby limit the price signal. It is uncertain to what extent taxes and levies actually limit the efficiency of demand response.

Levies are imposed with other purposes than promoting demand response. The structure of the levy should thus reflect the reasoning of the levy and not how it affects the volumes of demand response to price signals. One should however try to limit the possible negative effect that taxes and levies may have on the efficiency of price signals, e.g. may a measures to reduce taxes or levies in high price periods reduce the efficiency of the price formation.

\subsubsection{Measures to reduce costs of handling data}

In section 5.2.3 we describe requirements related to data management as a prerequisite for efficiency in demand response. Cost efficiency is in particular important for smaller consumers and smaller loads that require a high degree of standardization and solutions to be automatic. Easy access to data and efficient IT infrastructure will promote innovation in services and technology that may attract more flexibility to the market. Common Nordic solutions could further improve efficiency through more competition and opportunities to exchange flexibility between areas.

All the Nordic consumers will have smart meters by 2020 making data available real-time to consumers and possibly third parties such as a service provider or system operators (if technology allows and if consumers approve). A national or Nordic data hub may be an efficient way to facilitate this development. Regulations on the accessibility of other data could help limit the cost of demand response, including easy and standardised access to relevant market prices (e.g. spot prices, intraday prices and possibly prices in balancing and forward markets). Such access to information could improve the ability of service providers and home automation systems to provide demand response. Detailed requirements for such a standard data format should be made in consultation with service providers. Cost efficient data handling must be considered when the supplier centric model is implemented and should be 
included in assessments of functionality in national data hubs or other ways of handling measurement data from smart meters.

To further reduce the cost of data handling, the Nordic Governments could also demand that grid companies and suppliers provide information on their pricing in a predefined and standard format.

The communication channel set up to download measurement data from the smart meters to the grid companies' data systems, may increase safety and reduce the costs of sending demand response signals to consumers. This is in particular important to aggregators, BRPs and other service providers that want to send direct signals to a large number of small loads. Bandwidth limitations may restrict the amount of data and/or the frequency of the communication.

In order to ensure neutrality and competition service providers should as a minimum have access to the communication channels when it is not used by utilities for other purposes than downloading measurement data from consumers.

\section{Figure 19: Illustration of possible data streams to enable demand response}

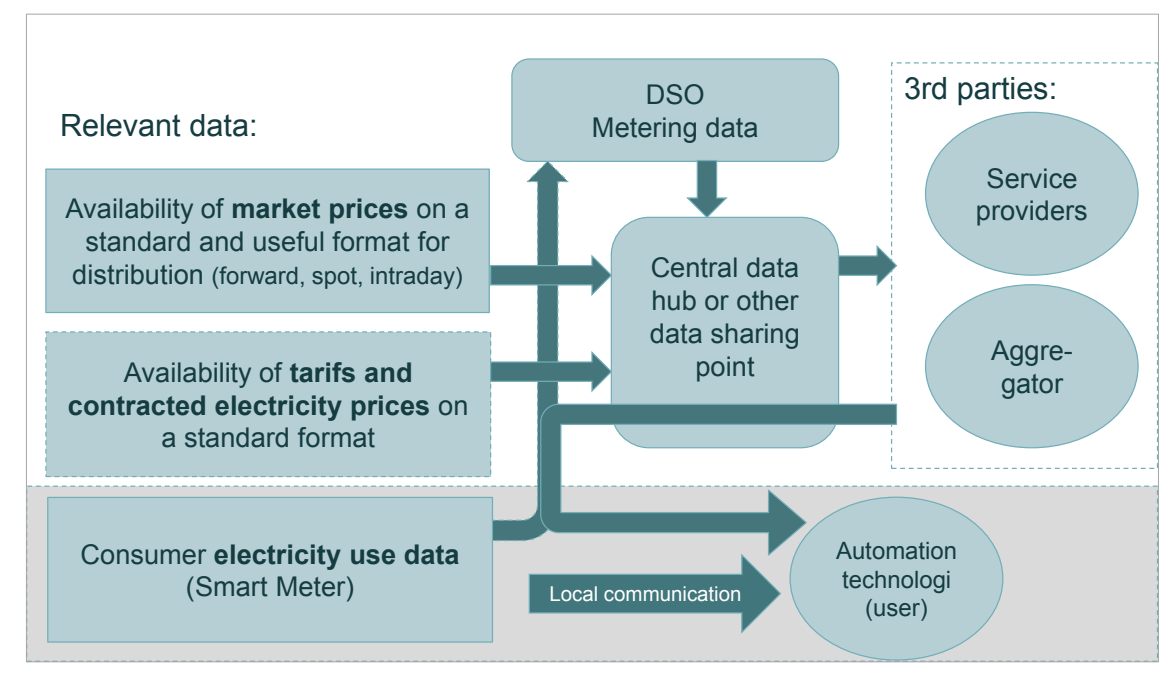

\subsubsection{Nordic standards}

Nordic governments may impose the use of new standards to promote efficiency and demand response. Standards may be relevant e.g. for electric equipment connected to grid (limit voltage disturbances, promote demand response) and for technical equipment like EV chargers, heat pumps, etc (limit voltage disturbances due to fast load changes).

Standards for equipment that may cause voltage disturbances may reduce grid problems (and therefore, the need for demand response). Details in such technical standards must be further assessed to evaluate both the need and the detailed requirements necessary. Standards may also be considered to ensure that loads and equipment (for instance heat 
pumps) that may provide flexibility are able to efficiently manage frequently shifting loads.

In general, the Nordic countries should follow international standards, and provide common standards in the Nordic market when no European or international standards are available.

\subsubsection{R\&D}

In chapter 4 we described developments and uncertainties. The future value of flexibility is uncertain due to uncertainty about how the changes in the power system may influence the need for flexibility. In our opinion, getting a better understanding of how the cost and value of demand flexibility will develop is crucial and should be focused in research.

Efficient markets and regulation will be essential to optimise the economics of the power system. Research on how to set up efficient market solutions can be done without knowing how the value of flexibility develops. In particular, research to improve the understanding of what actually drives the cost of investments and operation of DSOs and TSOs would be useful. Without such understanding, reflecting the underlying cost and cost drivers of the grid in the grid tariffs will be impossible.

Research on the technical potential for demand response is less important as long as one do not know how the price signals (the demand for flexibility) will develop. On the other hand, we think it is very relevant to evaluate consumers' price sensitivity towards the price signals given today. For instance, there are price signals in grid tariffs in (some areas) in all the Nordic countries. It should be possible to assess actual responses to actual price signals in today's market - especially for larger consumers. Smart meters have been in place for large customers and large buildings in all the Nordic countries, and by 2020 even small consumers will have Smart Meters installed. Studies of measure data may itself provide a lot more knowledge on electricity demand and usage, and also provide new insights on the potential price sensitivity of the consumers. In addition, differences between different types of consumers may be revealed.

On the technology side, we assume that the technology for demand response already exists. For small consumers, the costs may be a problem. R\&D may help bring costs down. Moreover, demonstration of technology may foster innovation and reduced costs of technology in this field. 



\section{Input to a nordic strategy for demand response}

A strategy for demand response has to consider developments and uncertainties discussed in chapter 4 and possible measures discussed in chapter 5. We observe that efficient use of demand flexibility requires efficient markets in general. Thus, market solutions should not be tailored to promote demand response especially as we argue that the future value of demand flexibility actually is uncertain. Regulation and markets should ensure utilization of the most cost efficient resources at all times, be it on the demand or the supply side. Increased granularity of time resolution in the spot markets and bidding closer to the operational hour could make more flexibility available to the market, and also reduce the need for balancing. More efficient allocation of grid capacity and redefinition of bidding zones could cater for more efficient spot price formation as well. Balancing markets can be improved by increased integration among the Nordic countries and harmonized product definitions across borders. Reduced bidding sizes (from 10 to $5 \mathrm{MW}$ is now tested), the duration of load adjustments, response times, and intervals between disconnections are (nonexhaustive) examples of product characteristic that should be assessed. Grid tariffs may incentivize increased end-user flexibility. Such grid tariffs should however not be implemented in order to increase flexibility, but in order to reflect underlying grid costs more efficiently.

The purpose of this project is to give input to the Nordic governments on a strategy on demand flexibility for the period up to 2025. In conclusion we give some input on how to develop strategies and recommend some measures to promote demand flexibility in a cost efficient way.

\subsection{Developing strategy under uncertainty}

A strategy for demand response has to consider developments and uncertainties discussed in chapter 4 and possible measures discussed in chapter 5 . Figure 20 illustrates possible future scenarios for the competitiveness of demands response. Demand response is obviously attractive in a scenario where the value of flexibility is high and the cost of demand flexibility is low compared to the cost of alternative sources of flexibility. 


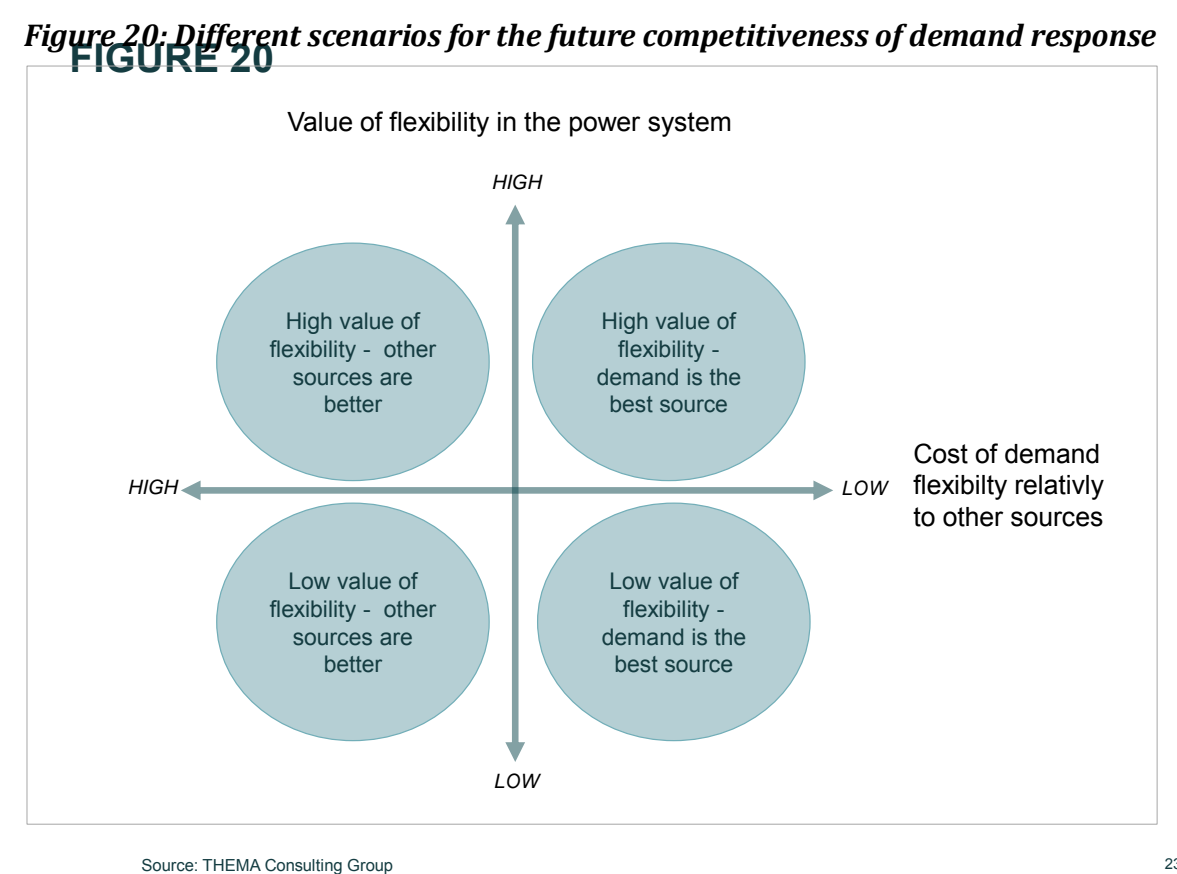

To develop a clear strategy is challenging when the future development is uncertain. In general, there are four overall alternatives for making a strategy under uncertainty:

1. Develop a strategy for what is considered to be the most likely development.

2. Develop strategies that will prove to be efficient in all scenarios.

3. Postpone strategic decisions:

a) Wait and see, but follow the development closely.

b) Aim to reduce the uncertainty by increasing knowledge.

4. Develop low cost (and low risk) strategic options to prepare for one or more scenarios.

Alternative one is a gamble, it entails picking one of the scenarios in Figure 20 and develop a strategy fit this scenario. If the scenario proves right, you win. If the future development is according to one of the other three scenarios your strategy will fail to address the future situation. We have argued that the future value of demand flexibility is uncertain - a strategy based on picking one possible future is therefore risky.

It is off course attractive to develop a robust strategy that works in all possible scenarios - if this is a realistic approach (alternative two). However, a combination of alternative two, three and four is also attractive catering for unforeseen developments not taken into consideration in all scenarios. 


\subsection{Overall recommendations for all Nordic countries}

As stated in chapter 4 , the long term value of flexibility and the competitiveness of demand as a provider of flexibility is not clearly understood, both due to uncertainty in the development of power consumption and the impact of new market solutions and new technology. This uncertainty should be addressed by pursuing three overall strategic objectives: promote efficient market solutions, increase the knowledge and understanding on the factors affecting the value of (demand) flexibility, and reduce the cost of demand response from small consumers by making relevant data easily available for consumers and third parties as a low cost, low risk measure.

\subsubsection{Efficient market solutions}

We observe that efficient use of demand flexibility requires efficient markets in general. Thus, market solutions should not be tailored to promote demand response. Regulation and markets should ensure utilization of the most cost efficient resources at all times, be it on the demand or the supply side. Some overall guidelines to promote efficient use of demand flexibility in power markets are:

- The cost of using flexibility in the day-ahead and intraday markets is in general less than applying it for balancing purposes in the realtime markets. Thus, limiting real-time imbalances by having an efficient day-ahead and intraday market is an attractive measure.

- All prices in the various market timeframes should reflect the real underlying cost (spot prices, intraday prices, balancing costs, grid tariffs and system services).

- Prices should be set in competitive markets and market solutions should be harmonised across borders and regions allowing for efficient cross border competition and sharing of resources.

- Avoid making interventions in the markets that may have adverse effects.

The Nordic power market has become increasingly integrated over the last 20 years, resulting in one of the world's most efficient power markets. The Nordic market is integrated in European solutions for dayahead and intraday markets as defined in European regulation (ENTSOE Grid Codes). The balancing market and retail market will however to a greater extent be developed regionally. Nordic Governments and regulators will thus have a role in developing and integrating balancing markets and retail markets in the region. Nordic governments and regulators may also contribute in the European process of developing target solutions for all market timeframes and sharing the Nordic experience 
as a frontrunner in the development of market solutions and of integrating markets across borders.

The plans for a common retail market, common balancing settlement and the increased focus on common balancing markets are examples of initiatives taken by Nordic Governments and regulators to improve the Nordic market design further. This work should continue. In sections 6.3.1 and 6.3.2, we identify possible improvements in market design.

\subsubsection{Understanding the cost and value of demand flexibility}

Increased efficiency in the Nordic market design could be the only measure to promote flexibility in the Nordic market. But, there is a risk that some improvements in the market design are not possible to implement during the next 10 years and/or that such improvements will not fully address future challenges, for instance in the balancing markets. Thus other measures may prove necessary to efficiently maintain security and quality of supply. Regulators and policymaker have to deal with the uncertainties related to the future demand for flexibility and the competitiveness of consumers as providers of flexibility (as illustrated in figure 18). Most of the research on demand flexibility focusses on how to promote demand response, whereas the relevant question is really what the cost and value of demand response will be. The starting point for research in this field should therefore be:

- Increase the understanding of how the planned changes in generation, consumption, grid investments, market solutions and new technology influence the future demand for flexibility in the Nordic power system.

- Increase the understanding of the characteristics of flexibility, its future value and the volumes needed.

- Assess potentials for supply of flexibility, differentiated based on the relevant characteristics identified above.

- Assess under which market and regulatory conditions the technical potentials are relevant.

- Identify market failures that may prevent demand flexibility.

The engagement of small consumers in the power market has so far been very limited. The lack of hourly measurement and smart meters may be one reason for this. The Nordic regulators should therefore seize the opportunity learn from the experience of the first movers in the field, i.e.:

- Finland: Monitor and evaluate the impact of the full roll-out of smart meters with hourly metering: 
a) Monitoring: Interesting indicators include changes in energy contracts (from fixed/time of use to hourly pricing), responses to price signals, the uptake of new products (like Fortum Fiksu and Helens Termo), entry of new service providers, and changes in consumption patterns.

b) Evaluation: How changes in consumer patterns affect the power system (spot prices, peak load in grid, and the demand for balancing services).

- Norway: Evaluate the effects of combined hourly measurement and hourly pricing on consumer behaviour in areas where the grid companies have installed smart meters at an early stage and where most consumers have spot price contracts.

- All Nordic countries: Most large buildings have installed smart meters for several years and have been able to exploit and explore the potential benefits of engaging in the power market. Assessment on how these consumers have responded to price signals in spot prices and/or grid tariffs could provide useful information on what to expect from smaller consumers.

\subsubsection{Making relevant data easily available for consumers and third parties}

Demand response from small electricity loads requires the transaction cost to be low. The cost of demand flexibility in buildings can be reduced by imposing standard formats on data/information, required for small consumers who respond to spot prices and grid tariffs. The service providers, enabling demand response, should also get access to the measured data collected from smart meters. The Nordic regulators should:

- Define useful data formats for grid tariffs, energy contracts, forward prices and day-ahead prices. Service providers of demand response (and energy efficiency) should be invited to give input on how different formats will influence the cost of data handling.

- Define efficient ways of making prices available for the consumers and third parties, included safe authorisation. In countries with national data hubs for electricity measure data, the hub may be a part of the solution. If no national hub is set up, other ways of communication have to be defined.

- Define for which services and how the two-way communication channel between the smart meter and DSO should be made available for third parties, and require DSOs to give third parties access accordingly. 
- Require DSOs, suppliers and Nord Pool Spot to provide their data on standard formats and make prices available to consumers and third parties.

It is likely that the most efficient approach is coordinated implementation across the Nordic region. All differences between national markets will to some extent act as market barriers to cross-border competition for service providers and for the penetration of new technology.

\subsection{Recommendations per market area}

In this section, we summarize our recommendations on measures to efficiently promote demand flexibility in the Nordic power system. We distinguish between measures promoting demand flexibility in the spot market, in the provision of system services and in order to reduce grid costs.

\subsubsection{The spot price formation}

Nordic spot price formation is already market based and highly efficient compared to most other power markets. Further development is however still desirable:

- Assess the costs and benefits of changes in the Nordic spot market design, in particular, how changes in the market design will influence the demand (and cost) of balancing services. Potential changes to assess:

a) shorter time resolution (from hourly to 15 minutes)

b) market closure closer to the operating hour

c) more accurate capacity allocation of grid

d) bidding zones defined by physical constraints and by national borders

e) consider new products that promote flexibility (in addition to e.g. flexible one-hour bids)

- Develop a road map for implementation of changes in the Nordic spot market design and possibly in the North West Europe spot market design.

Price formation should reflect the price sensitivity on the demand side, including the price sensitivity of small consumers. Retailers will indirectly include the price response of small consumers in their bids - provided that retailers can predict the demand response. However, TSOs and DSOs may aggregate and activate consumer flexibility or use it to reduce peak loads in a manner that is unpredictable for the consumers' retailer. 
If that is the case, such service providers should be required to be balance responsible parties:

- Aggregators, and other market service providers enabling demand response on other than day-ahead spot prices, should be balance responsible parties.

- Such regulation will be most effective if implemented in a coordinated manner in the Nordic region in line with the implementation of a common balancing settlement in Finland (2015), and Sweden and Norway (2016).

\subsubsection{Balancing markets}

All measures to increase efficient settlement of the spot prices, as described above, serve to limit the imbalances occurring after gate closure, and may thus reduce the need for balancing resources. If changes in the market design in the spot markets are decided, the implications on the demand for balancing markets should be evaluated. Making the energy market work as efficiently as possible is thus crucial for balancing markets as well.

The Nordic regulators should however consider the following measures specifically aimed at improving the balancing markets:

- Assess how products should be designed to increase the participation of generators and consumers (the bid size, duration, recovery time and response time).

- Assess the costs and benefits of extending the mandatory implementtation of autonomous operation to facilitate system frequency control for consumers both at TSO and DSO level.

- Define a target model for balancing markets and implement common Nordic balancing markets.

- Work closely together with TSOs to assess and implement improved market design for balancing. If a Nordic cooperation is not established, the national regulator and TSO should continue this work on a national level.

\subsubsection{Peak load in local grids}

The economic regulation of DSOs in the Nordic countries is generally based on income caps. This implies that DSOs have incentives to stimulate demand flexibility when this is the most cost efficient solution.

Peak load in the local grid is only a challenge if the capacity in the local grid is scarce. Both the roll-out of smart meters and increasing implementation of Smart Grid elements in the local grids will provide better information on existing loads related to the capacity in the grid. 
Grid tariffs according to marginal losses, interruptible contracts and capacity pricing may incentivize increased end-user flexibility. Such grid tariffs should however not be implemented in order to increase flexibility, but in order to reflect underlying grid costs more efficiently. However, improved grid tariff structures could stimulate increased consumer flexibility. National regulators should therefore:

- Assess the underlying cost drivers for grid investments and operation.

- Impose grid tariffs that reflect the underlying costs.

A potential cost driver in local grids may be appliances that cause voltage disturbances. Thus, national regulators should:

- Assess the implication different electrical appliances has on voltage disturbances.

- Evaluate the cost benefit of imposing technical standards on electrical appliances (for instance heat pumps, charges of EVs, tankless water heaters etc) to avoid negative impact on the quality of power in local grids. 


\section{References}

Cajar, P. D. $(2013,1128)$. Interview of head of future grid development \& strategy at Dong Energy. (K. Fiksen, \& S. Harsem, Interviewers)

Dansk Energi (2013): Mulighederne for den fremtidigige fjernvarmeproduktion i decentrale områder.

Dong (2014). Priser fra 1. april 2014. Hentet fra Dong Energy Distribution: http://www.dongenergydistribution.dk/DA/ERHVERV/ELDISTRIBUTION/PRISER\%200G\%20GEBYRER/P ages/Prisergebyrer2012_ny.aspx

EA Energianalyse. (2011). Kortlægning af potentialet for fleksibelt elforbrug i industri, handel og service. København: EA Energianalyse.

Elforsk. (2006a). Demonstrationprojekt. Effektstyrning på användarsidan vid effektbristsituationer. Elforsk.

Elforsk (2006b). Studie av effektreduktioner hos mellanstora kunder. Elforsk.

Elforsk (2013): Efterfrågeflexibilitet på en energy-only marknad. Budgivning, nättariffer och avtal. Elforsk rapport 13:95

Energia (2014): Energy Year 2013 - Electricity. Presentation downloaded from Energia.fi.

Energimyndigheten. (2014). Prisutveckling på el och naturgas samt leverantörsbyten, fjärde kvartalet 2013. Eskilstuna: Energimyndigheten.

Fingrid (2013): National ten-year grid development plan for Finland. Presentation downloaded from Fingrid.fi.

Fingrid (2014): Increasing flexibility in the electricity market. Presentation held by Jonne Jäppinen at the Fingrid Electricity Market Day, 7th of Aprile 2014

Fortum $(2014,0326)$. Elöverföringspriser. Hentet fra Fortum:

http://www.fortum.com/countries/fi/yksityisasiakkaat/tjanster-pasvenska/eloverforing-och-anslutning-tillelnatet/eloverforingspriser/pages/default.aspx

Gaia (2011): Examining and proposing measures to activate demand flexibility on the Nordic wholesale electricity market

Grønn Bil (2013): Elbil i distribusjonsnettet: Eksploderende transformatorer, eller billig effektregulering? Presentation held by Ole Henrik Hannisdahl at Nettkonferansen 27th of November 2013

Helsingin Energia. (2014, 03 25). Elöverföringspriser. Hentet fra Helsingin Energia: http://www.helen.fi/sv/For-hushall/Tjanster/Elnatet/Eloverforingspriser/

Jäppinen, J. (2013, 12 12). Interview of development manager at Fingrid Oyj. (A. Skånlund, \& S. Harsem, Interviewers)

Klimakomissionen (2010): Grøn energi - vejen mod et dansk energisystem uden fossile brændsler

NEPP (2013). Förutsätningar och drivkrafter för olika typer av elkunder att justera förbrukningsmönster och minska sin elförbrukning idag och i framtiden. Stockholm: North European Power Perspectives.

NordReg (2013). Nordic Market Report 6:2013. Oslo: NordReg.

NordReg (2013b). Nordic harmonisation of universal service supply obligations. Oslo: Nordic Energy Regulators.

NVE. (2013). Hovedtall fra NVEs Leverandørskifteundersøkelse 1. kvartal 2013. Oslo: Norges vassdrags- og energidirektorat. 
NVE (2014): Energibruksrapporten 2013 - Fremtidens energibruk i bygninger.Rapport nr 11/2014. Oslo: Norges vassdrags- og energidirektorat.

SINTEF (2012): Håndtering av utfordrende elektriske apparater som tilknyttes distribusjonsnettet. Commissioned by Energi Norge

Statnett (2012): Systemdrift og markedsutviklingsplanSVK (2002). Industribud Delutredning i effektbalansutredningen. Svenska Kraftnät.

SVK (2013). Perspektivplan 2025 - En utvecklingsplan för det svenska stamnätet. Sundbyberg: Svenska Kraftnät.

SWECO (2011): Systemeffekter av timvis mätning. En rapport for Näringsdepartementet.

Söderström, B. O. $(2013,1125)$. Interview of strategy and regulation manager at Vattenfall/Smart grids portofolio mananger at Vattenfall. (K. Fiksen, \& S. Harsem, Interviewers)

Techcrunch.com (2014): Apple's Home Automation Success Rests With Hardware Evangelism. Article downloaded from the site www.techcrunch.com in June 2014.

THEMA og Devoteam daVinci (2011): AMS—Tilleggstjenester. Tredjepartsadgang. THEMA (2013a): Kapasitet og tilgjengelighet for oljefyring. THEMA Notat 2013-02. Commisioned for The Norwegian Ministry of oil and energy.

THEMA (2013b):

THEMa (2013c): Barrierer i sluttbrukermarkedet for strøm. THEMA rapport 2013-25. Utført på oppdrag for NVE.

The Finnish government. (2012). Regeringens proposition till riksdagen med förslag till ändring av lagstiftningen om el- och naturgasmarknaden. .

Toivonen, J. (2013, 11 27). Head of Electricity Sales and Marketing at Fortum. (K. Fiksen, \& S. Harsem, Interviewers)Vattenfall (2014, 03 26). Elnätspriser. Hentet fra Vattenfall:http://www.vattenfall.se/sv/elnatspriser.htm

VTT (2007): Demand Response in Nordic countries. A presentation held by Seppo Kärkkäinen at a workshop on demand response in Seoul Palace hotel, Korea, the $18^{\text {th }}$ of April 2007

Wired.com (2014): What Google really gets out of buying Nest for $\$ 3.2$ billion. Article downloaded from the site www.wired.com in May 2014. 


\section{Sammendrag}

Denne rapporten er utarbeidet på opdrag fra Elmarkedsgruppen (Nordisk ministerråd) og gir innspill til hvordan forbrukerfleksibilitet kan fremmes på en effektiv måte i de nordiske landene.

Rapporten er del av de nordiske statsministrenes initiativ for grønn vekst: "Norden - ledende i grønn vekst". Les mer i nettmagasinet "Green Growth the Nordic Way" på www.nordicway.org eller på www.norden.org/greengrowth

Kraftsystemet er etablert for å møte forbrukernes behov. I kraftforsyningen må det til enhver tid være balanse mellom produksjon og forbruk. Den løpende balansen mellom forbruk og produksjon har primært vært sikret ved at kraftproduksjon har tilpasset seg forbruk (produksjonsfleksibilitet). For at forbrukerfleksibilitet skal utnyttes, må forbrukssiden ha en viss prissensitivitet. I dagens situasjon er det i all hovedsak kraftintensiv industri som tilpasser forbruket ved høye kraftpriser og som tilbyr sin fleksibilitet i markedet, men også kombinasjonen av olje- og elkjeler har bidratt med fleksibilitet i alle de nordiske landene.

Kraftsystemet er nå i betydelig omstilling. Mer fornybar energi fases inn, markedene blir integrert på tvers av land og regioner og ny teknologi skaper nye muligheter for å utnytte ressursene i kraftsystemet. De senere år har det vokst frem forventninger om at smarte løsninger i kraftsystemet (f.eks. AMS i private hjem) vil gi en betydelig økning i forbrukerfleksibiliteten og at kraftsystemet er avhengig av denne fleksibiliteten for å klare fornybaromstillingen.

Vi tror det er gode grunner til å nyansere, og kanskje dempe, forventningene til forbrukerfleksibilitetens rolle i fremtiden. Forbrukerfleksibilitet er ikke et mål i seg selv. Fleksibilitet er et middel for å effektivt balansere kraftsystemet, herunder håndtere forbrukstopper, uforutsette avvik i produksjon/forbruk og utfall/hendelser i kraftsystemet. Forbrukerfleksibiliteten er attraktiv i den grad den er konkurransedyktig i forhold til annen type fleksibilitet.

$\mathrm{Vi}$ anser to forhold som særlig viktige i arbeidet med å utvikle en nordisk strategi for forbukerfleksibilitet:

- Etterspørsel etter fleksibilitet: Særlige tiltak for å fremme forbrukerfleksibilitet bør ikke igangsettes uten en dypere forståelse av den framtidig etterspørseln etter fleksibilitet og for hvordan denne etterspørselen best kan dekkes. 
- Markedet: En nordisk strategi for forbrukerfleksibilitet bør sikre effektiv utnyttelse av fleksibiliteten i kraftsystemet generelt uavhengig av om fleksibiliteten kommer fra forbruk, produksjon, lagring eller ved forsterkinger av kraftnettet.

I det følgende drøfter vi de to forholdene nevnt ovenfor mer inngående.

\subsection{Forstå etterspørselen etter fleksibilitet bedre}

Mange peker på at en økende andel uregulerbar kraftproduksjon og flere utenlandsforbindelser vil øke behovet for fleksibilitet i kraftsystemet og at dette behovet må dekkes av forbrukerfleksibilitet. Spesifikke tiltak mot forbrukssiden vil normalt være mindre effektivt enn generelle tiltak, f.eks gjennom markeder, og bør derfor kun benyttes dersom det er særskilte årsaker til det. Vi kan ikke se at behovet for forbrukerfleksibilitet er tilstrekkelig dokumentert, og mener at spesifikke tiltak for å fremme forbrukerfleksibilitet, særlig fra små forbrukere, ikke bør settes i verk uten en bedre forståelse av hvilke problemer som skal løses ved en aktivisering av forbrukerne.

Det er tre forhold som må dokumenteres bedre for å forsvare spesifikke tiltakt for å fremme forbrukerfleksibilitet:

- Hvordan vil endringene i kraftproduksjon, forbruk, nettstruktur, teknologi og regulering vil påvirke behovet for fleksibilitet $\mathrm{i}$ kraftsystemet? Økt andel uregulerbar kraftproduksjon, flere utenlandsforbindelser og redusert forbruk i kraftintensiv industri vil bidra til økt prisvolatilitet og etterspørsel etter fleksibilitet. Men samtidig vil økt nettkapasitet og økt markedsintegrasjon i det nordiske kraftsystemet bidra til at dagens fleksibilitet kan utnyttes bedre og over større områder. Det er dermed ikke gitt hvordan etterspørselen etter fleksibilitet vil utvikle seg samlet sett og for ulike områder i Norden.

- Hvordan vil etterspurte egenskaper ved fleksibilitet utvikle seg? Egenskaper ved fleksibilitet hovedsakelig relatert til ulike tidsaspekter som varighet, responstid og nødvendig innetid før lasten igjen kan kobles ut.

- Hvilke deler av kraftsystemet har fleksibilitet med de etterspurte egenskapene? Alternative måter å dekke behovet for fleksibilitet er økt utnyttelse av fleksibilitet i kraftproduksjon (inkludert uregulerbar produksjon), energilagring og import (styrking av kraftnettet). Det er ikke gitt at forbrukersiden kan bidra med fleksibilitet av en slik varighet og pålitelighet som etterspørres eller at forbruk er den mest kostnadseffektive leverandøren av slik fleksibilitet. 
Behovene for fleksibilitet kan videre variere mellom land og mellom ulike områder innenfor hvert land. Sammensetningen av produksjon og forbruk i området og nettkapasiteten til områdene rundt vil påvirke både behovet for fleksibilitet, etterspurte egenskaper og hvem som er den beste leverandøren av fleksibilitet.

Fleksibilitet fra forbrukerene, og da særlig mindre forbrukere, vil være krevende å aktivere med lave kraftpriser og få pristopper som følge av en sterk kraftbalanse de neste 10 årene. Det å kunne øke forbruk i perioder med svært lave priser kan imidlertid være en driver for de forbrukerne som har muligheter til det, for eksempel fjernvarmeleverandører.

\subsection{Utnytte billig fleksibilitet før dyr fleksibilitet gjennom effektive markeder}

Markedsmekanismen brukes for å sikre effektiv utnyttelse av fleksibilitet i kraftsystemet. Nordpool Spot driver den nordiske markedsplassen for handel med kraft. Det nordiske markedet er nå koblet til andre europeiske markeder (markedskobling) med løsninger som sikrer effektiv utnyttelse av produksjon, forbruk og infrastruktur på tvers av land og regioner. Etter at spotmarkedet stenger håndterer TSOene ubalansene ved handel i balansemarkedet. I balansemarkedet kjøper TSOene ulike typene fleksibilitetsprodukter som de bruker for å sikre stabil kraftforsyning i driftstimen. Det vil normalt være rimeligere å avklare tilgangen på fleksibilitet i det åpne markedet før driftstimen enn å benytte balansetjenester i driftstimen.

Noen aktuelle tiltak for å realisere fleksibilitet på en effektiv måte i dagens markeder kan være:

- Spotmarkedet. En finere tidsoppløsning i spotmarkedene (15 minutter fremfor en time) og budgivning nærmere driftstimen (evt. også markedsklarering flere ganger i døgnet fremfor en gang) vil bidra til både gjøre produksjonsplanene mer treffsikre og gjøre mer kortsiktig fleksibilitet tilgjengelig i spotmarkedet og derved redusere behovet for balansering. En mer effektiv allokering av nettkapasitet og en definering av budområdene slik at de bedre reflekterer fysiske flaskehalser (og ikke landegrenser) vil kunne ha en tilsvarende positiv effekt. Disse tiltakene kan gjøre betydelig mer fleksibilitet tilgjengelig $\mathrm{i}$ markedet. Tiltakene kan i utgangspunktet synes enkle og billige, men det kan ta tid å implentere dem siden markedsløsningene kobler mange land og regioner og siden partene som eier løsningene i fellesskap må bli enige. Likevel er det grunn til å anta at effektive løsninger over tid vil vinne frem og bli etablert. 
- Balansemarkedet. Tilsvarende er det grunn til å anta at markedsløsningene (innkjøpsordningene) i TSOenes balansemarkeder også effektiviseres. I de senere år er det flere eksempler på at mye ny produksjonsfleksibilitet blir synliggjort når TSOene endrer produktspesifikasjonene og aksepterer lavere bud (f.eks. bud ned mot $5 \mathrm{MW}$ fremfor $10 \mathrm{MW}$ ), når de kjøper reserver daglig/ukentlig fremfor månedlig/kvartalsvis og når de akepterer ulik responstid og varighet på budene. Disse tiltakene kan man i større grad gjennomføre nasjonalt og/eller på nordisk nivå da det ennå ikke er etablert europeiske løsninger.

- Balanseansvar til aggregatorer. For å sikre like konkurransevilkår og effektive utnyttelse av fleksibilitet er det viktig at aktører som aggregerer opp mange forbrukeres fleksibilitet også har balanseansvar.

I tillegg er nettariffer en viktig del av markedsløsningen og gir effektive incentiver til fleksibilitet i produksjon og forbruk dersom de reflekterer nettkostnadene (drift og investering) i kraftnettet.

Vi har pekt på at det ikke bør rettes spesifikke tiltak for å fremme forbrukerfleksibilitet uten at behovet er grundigere dokumentert. Imidlertid kan man iverksette tiltak som har en lav kostnad, og som på sikt kan vise seg å ha stor betydning dersom behovet for forbrukerfleksibilitet øker på lengre sikt. Vi foreslår ett slikt tiltak:

- Standardisering av datahåndtering til små forbrukere. For at små forbrukere skal kunne reagere på prissignaler, er det avgjørende med automatisering. Et krav om standardisering av all relevant pris- og markedsinformasjon vil bidra til at tredjeparter kan tilby teknologi og tjenester for automatisk prisrespons fra små forbrukere. 


\section{Attachment 1: List of interviewees}

\begin{tabular}{|c|c|c|c|c|c|}
\hline Interviewee & Title & Company & & Country & \\
\hline Karin Widegren & Secretary director & $\begin{array}{l}\text { Samordningsrådet för } \\
\text { smarta elnät }\end{array}$ & Organization & Sweden & Meeting \\
\hline Karima Björk & $\begin{array}{l}\text { Committee Secretary, } \\
\text { Electricity markets }\end{array}$ & $\begin{array}{l}\text { Samordningsrådet för } \\
\text { smarta elnät }\end{array}$ & Organization & Sweden & Meeting \\
\hline Zarah Andersen & Market design analyst & Svenska Kraftnät & TSO & Sweden & Meeting \\
\hline Bo Olsson & $\begin{array}{l}\text { Strategy and regulatory } \\
\text { manager }\end{array}$ & Vattenfall & DSO & Sweden & Meeting \\
\hline Peter Söderström & $\begin{array}{l}\text { Smart Grids Program } \\
\text { Manager }\end{array}$ & $\begin{array}{l}\text { Vattenfall distribution } \\
\text { Nordic }\end{array}$ & DSO & Sweden & Meeting \\
\hline Magnus Thorstensson & Senior economist & Svensk Energi & Organization & Sweden & Meeting \\
\hline Magnus Lindén & Project manager & Sweco Energuide & Consultancy & Sweden & Phone \\
\hline Bernt A. Bremdal & Special advisor R\&D & $\begin{array}{l}\text { NCE Smart Energy } \\
\text { Markets }\end{array}$ & Organization & Norway & Phone \\
\hline $\begin{array}{l}\text { Ellen Kristine Strøm } \\
\text { Juliussen }\end{array}$ & Advisor-Market design & Statnett & TSO & Norway & Meeting \\
\hline Erik Alexander Jansson & Engineer (M.S.) & Statnett & TSO & Norway & Meeting \\
\hline Eilert Henriksen & CEO & $\begin{array}{l}\text { Fredrikstad } \\
\text { EnergiNett AS, }\end{array}$ & DSO & Norway & Meeting \\
\hline Kay Normann Sjursen & $\begin{array}{l}\text { Head of industrial Power } \\
\text { Portfolio and Projects }\end{array}$ & Norsk Hydro & Industry & Norway & Meeting \\
\hline Jukka Toivonen & $\begin{array}{l}\text { Head of Electricity Sales } \\
\text { and Marketing }\end{array}$ & Fortum & Retailer & Finland & Meeting \\
\hline Sami Sailo & $\begin{array}{l}\text { Unit manager, Electricity } \\
\text { solutions }\end{array}$ & Helsingin Energia & DSO/Retailer & Finland & Meeting \\
\hline Markku Hyvärinen, & Head of Development & Helsingin Energia & DSO/Retailer & Finland & Meeting \\
\hline Jan Segerstam & Development Director & Empower Oy & Organization & Finland & Meeting \\
\hline Fredrik Lasén & Solutions Advisor & There Corporations & Service provider & Finland & Meeting \\
\hline Jonne Jäppinen & Development Manager & Fingrid & TSO & Finland & Phone \\
\hline Peder Dybdahl Cajar & $\begin{array}{l}\text { Head of future grid } \\
\text { development \& strategy }\end{array}$ & Dong Energy & DSO & Denmark & Meeting \\
\hline Sune Thorvildsen & Senior Advisor & $\begin{array}{l}\text { The Confederation of } \\
\text { Danish Industry }\end{array}$ & Organization & Denmark & Meeting \\
\hline Göran Wilke & CEO & IC-Meter & Service provider & Denmark & Meeting \\
\hline Ulrik Stougaard Kiil & Market developer & Energinet.dk & TSO & Denmark & Phone \\
\hline
\end{tabular}


Ved Stranden 18

DK-1061 Copenhagen K

www.norden.org

\section{Demand response in the Nordic electricity market}

Consumer flexibility is often mentioned as a solution that can contribute to improved price formation in spot markets, increase supply of system services and potentially reduce local grid investments and operation costs. This report provides input to a Nordic strategy on how to address the potential need for consumer flexibility in a cost-efficient manner. The main recommendation is to focus on increased market efficiency in general, and not to promote specific measures on the demand side unless market failures are identified. However, it is recommended that standard data formats on price signals to small consumers should be further assessed.

The report is part of the Nordic Prime Ministers' overall green growth initiative: "The Nordic Region - leading in green growth" - read more in the web magazine "Green Growth the Nordic Way" at www.nordicway.org or at www.norden.org/greengrowth
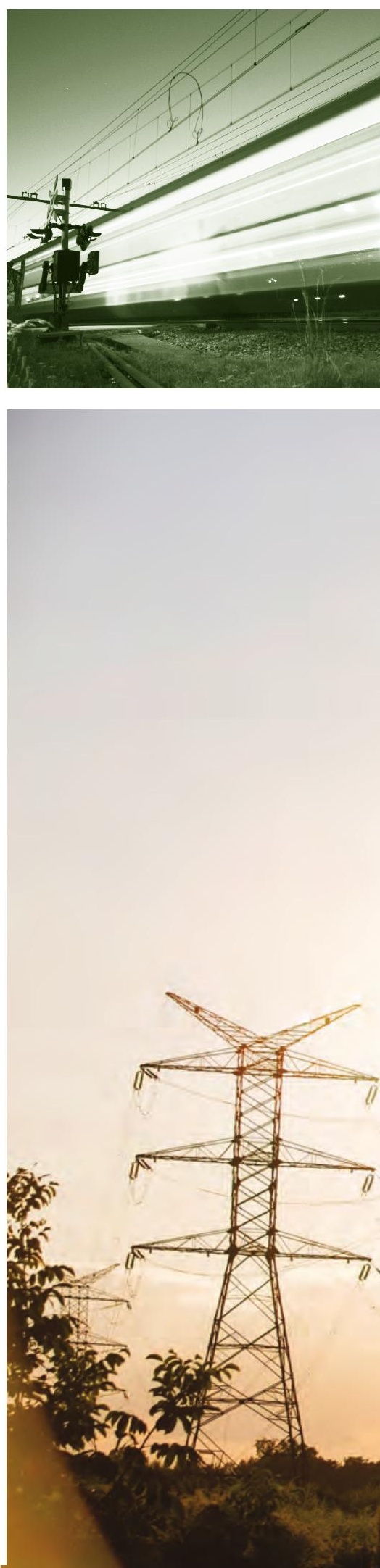